\title{
The Neapolitan Yellow Tuff caldera offshore the Campi Flegrei: Stratal architecture and kinematic reconstruction during the last $15 \mathrm{ky}$
}

\author{
M. Sacchi ${ }^{\text {a,* }}$, F. Pepe ${ }^{\text {b }}$, M. Corradino ${ }^{\text {b }}$, D.D. Insinga ${ }^{\text {a }}$, F. Molisso ${ }^{\text {a }}$, C. $^{\text {Lubritto }}{ }^{\text {c }}$ \\ a Istituto per l'Ambiente Marino Costiero (IAMC), Consiglio Nazionale delle Ricerche (CNR), Calata Porta di Massa, 80133 Napoli, Italy \\ b Dipartimento di Scienze della Terra e del Mare (DiSTeM), Università di Palermo, Via Archirafi, 22, Palermo, Italy \\ c Dipartimento di Scienze e Tecnologie Ambientali, Biologiche e Farmaceutiche, Seconda Università di Napoli, Via Vivaldi, 43, 81100 Caserta, Italy
}

\section{A R T I C L E I N F O}

\section{Article history:}

Received 19 April 2013

Received in revised form 14 April 2014

Accepted 19 April 2014

Available online 26 April 2014

Communicated by J.T. Wells

\section{Keywords:}

Campi Flegrei

Neapolitan Yellow Tuff

collapse caldera

ring fault system

caldera resurgence

Late Quaternary

\begin{abstract}
A B S T R A C T
In this study we integrate high-resolution swath bathymetry, single channel reflection seismic data and gravity core data, to provide new insights into the shallow structure and latest Quaternary to Holocene evolution of the submerged sector of the Neapolitan Yellow Tuff (NYT) caldera (Campi Flegrei) in the Pozzuoli Bay. The new data allow for a reconstruction of the offshore geometry of the NYT caldera collapse-ring fault system, along with the style and timing of deformation of the inner caldera resurgence.

Our interpretation shows that the NYT eruption $(\sim 15 \mathrm{ka} \mathrm{BP})$ was associated with a caldera collapse bounded by an inward-dipping ring fault system. The ring fault system consists in a 1-2 km wide fault zone that encircles an inner caldera region $\sim 5 \mathrm{~km}$ in diameter and is often marked by the occurrence of pore fluids ascending through the fault zone, up to the seafloor, particularly in the western sector of the bay. A shallow magmatic intrusion along the ring fault zone was also detected offshore Bagnoli in the eastern part of the Pozzuoli Bay.

Following the NYT eruption, the inner caldera region underwent significant deformation and resurgence with a maximum cumulative uplift of the offshore structure in the order of $180 \mathrm{~m}$. The net uplift rate of the caldera resurgent dome was 9-12 mm/year during the period 15.0-6.6 ka BP. The style of deformation of the resurgent structure can be described in terms of a broad doming, accompanied by subordinate brittle deformation, mostly concentrated in a small apical graben at the summit of the resurgent dome.

Chronostratigraphic calibration of seismic profiles obtained by three tephra layers cored in the Pozzuoli Bay indicates 5 to $25 \mathrm{~m}$ of post-Roman differential subsidence and tilting towards ESE of the inner caldera resurgence, as recorded by the drowning of the infralittoral prograding wedge below the present-day storm wave base.
\end{abstract}

(c) 2014 Elsevier B.V. All rights reserved.

\section{Introduction}

Resurgent calderas are among the largest and most dynamic volcanic structures on earth. They are typically associated with major eruptions with huge volumes of pyroclastic deposits accompanied by large collapse structures and late stage deformation and uplift of the intra caldera floor region (Smith and Bailey, 1968; Henry and Price, 1984; Lipman, 1984, 1997; Komuro, 1987; Newhall and Dzurisin, 1988; Cole et al., 2005; Acocella, 2008; Kennedy et al., 2012).

Traditionally, the understanding of collapse calderas has been based on field studies, borehole data, remote sensing, gravity and seismic data (e.g. Smith and Bailey, 1968; Lipman, 1984, 1997, 2000; Walker, 1984; Cole et al., 2005) which allow identification of the caldera-forming products and the resulting caldera structure. A significant advance in

\footnotetext{
* Corresponding author at: Istituto per l'Ambiente Marino Costiero - IAMC, Consiglio Nazionale delle Ricerche - CNR, Calata Porta di Massa, Porto di Napoli, 80133 Napoli, Italy. Tel.: + 39081 5423840; fax: + 390815423888

E-mail address: marco.sacchi@iamc.cnr.it (M. Sacchi).
}

the understanding of caldera formation has been made in the last decades by the application of mathematical, finite element and scaled analogue models (Druitt and Sparks, 1984; Burov and Guillou-Frottier, 1999; Acocella et al., 2000, 2001; Roche et al., 2000).

At deeply eroded ancient calderas (e.g. Kokelaar, 1992; Branney and Kokelaar, 1994; Moore and Kokelaar, 1998), intracaldera deposits and structures are generally well exposed in the outcrop. On the contrary, it is often difficult to map young (i.e. $<2 \mathrm{Ma}$ ) and restless calderas, as the internal structure of the caldera and the ring fault system are commonly buried beneath significant accumulations of intracaldera ignimbrite and postcaldera deposits (Kennedy and Stix, 2003; Martí et al., 2009).

Although often modified by resurgence, the caldera structure is largely dominated by its collapse history. As a consequence, a clear comprehension of the subsurface structure and associated ring fault geometry is of great importance to understand the mechanisms responsible for resurgence and unrest in active calderas. One of the unsolved problems, for instance, is the understanding of the specific role and the interplay of the deep caldera structure and shallow structures in controlling the caldera unrest (Martí et al., 2009). 
The Campi Flegrei is an active volcanic area located on the coastal zone of the Campania region of SW Italy, a large part of which develops off the Naples (Pozzuoli) Bay. The area has been active since at least $\sim 80$ ka BP (Pappalardo et al., 1999; Scarpati et al., 2013), and is structurally dominated by a caldera collapse, $\sim 8 \mathrm{~km}$ in diameter, associated with the eruption of the Neapolitan Yellow Tuff (NYT), a $30-50 \mathrm{~km}^{3}$ Dense Rock Equivalent ignimbrite dated $\sim 15$ ka BP (Deino et al., 2004).

In the past decades the shallow crustal structure of the NYT caldera has been mostly reconstructed using gravimetric and magnetic data (e.g. Rosi and Sbrana, 1987; Barberi et al., 1991; Florio et al., 1999; Capuano et al., 2013). In the Pozzuoli Bay, the structural elements of the caldera collapse have been largely inferred, on the basis of seafloor morphology and associated deposits (Pescatore et al., 1984; Fusi et al., 1991; Fevola et al., 1993; Orsi et al., 1996; Di Vito et al., 1999). More recently, Capuano and Achauer (2003), Judenherc and Zollo (2004) and Dello Iacono et al. (2009) have documented the southern border of the NYT caldera down to a depth of $0.25-0.5 \mathrm{~km}$ beneath the seafloor, using low-resolution active seismic tomography images. Acocella et al. (2004) and Acocella (2010) describe the occurrence of the caldera collapse and resurgence dome in the Campi Flegrei district on the basis of modelling (analogue) experiments.

Despite the conspicuous research work conducted offshore the Campi Flegrei area during the last decades, the stratigraphic architecture of the NYT caldera collapse structure and resurgence, are still poorly understood. This is mostly because of the intrinsic limitations associated with the poor resolution and of published seismic datasets, as well as to the lack of reliable geologic calibration of the offshore geophysical data (e.g. Pescatore et al., 1984; Milia, 1998; Milia and Torrente, 2000; Bruno, 2004).

In this study we present a detailed stratigraphic reconstruction of the submerged part of the NYT caldera obtained by integration of swath bathymetry, high-resolution single channel reflection seismics and gravity core data recently acquired from the Pozzuoli Bay. The high-resolution reflection seismic data offer unprecedented detailed insights into the stratigraphy and shallow structure of the NYT caldera collapse-ring fault zone-inner resurgence system.

The results of this research may provide significant contribution to the understanding of the structural style and timing of deformation of restless resurgent calderas in the geodynamic context of active continental margins.

\section{Geological framework}

The Campi Flegrei district is an active volcanic area located between the western flank of Southern Apennines and the eastern Tyrrhenian margin (Fig. 1). This area is the result of large-scale lithospheric extension that developed in the Eastern Tyrrhenian back-arc region since the Late Neogene and represents a zone of transition within the upper plate of the Adria-Ionian subduction zone between the central Tyrrhenian spreading centre and Southern Apennine fold and thrust belt (Malinverno and Ryan, 1986; Oldow et al., 1993; Sacchi et al., 1994; Ferranti et al., 1996; Sartori et al., 2004; Faccenna et al., 2007 and references therein).

The volcanic activity of the Campi Flegrei spans throughout the latest Quaternary (Di Girolamo et al., 1984; Lirer et al., 1987; Rosi and Sbrana, 1987; Di Vito et al., 1999; Pappalardo et al., 1999; Rolandi et al., 2003; Scarpati et al., 2013) and is characterized by at least one large caldera collapse structure, produced during the eruption of the NYT, a 30-50 km³ Dense Rock Equivalent (DRE) ignimbrite dated at $\sim 15 \mathrm{ka}$ BP (Deino et al., 2004). The caldera is represented by a quasi-circular area of $\sim 8 \mathrm{~km}$ in diameter, that developed in the central sector of the Campi Flegrei, including the inland area and part the Pozzuoli Bay (Fig. 1) (Lirer et al., 1987; Rosi and Sbrana, 1987; Barberi et al., 1991; Scandone et al., 1991; Scarpati et al., 1993; Wohletz et al., 1995; Orsi et al., 1996; Florio et al., 1999; Judenherc and Zollo, 2004; De Natale et al., 2006; Dello Iacono et al., 2009; Sacchi et al., 2009).
Following the NYT eruption, the evolution of the Campi Flegrei was dominated by hydromagmatic activity with occasional plinian phases and minor effusive activity forming lava domes (Di Vito et al., 1999). Several tens of monogenic phreato-magmatic vents including tuff rings, tuff cones, cinder and spatter cones, have been active in the last 15 kyr mostly inside the NYT caldera collapse (de Vita et al., 1999; Di Vito et al., 1999; Insinga et al., 2006; Di Renzo et al., 2011; Fedele et al., 2011). The last event was the Monte Nuovo eruption in 1538 A.D., which occurred after some 100 years of caldera uplift (Parascandola, 1946; Di Vito et al., 1987; Morhange et al., 1999; D'Oriano et al., 2005; Piochi et al., 2005; Bellucci et al., 2006; De Natale et al., 2006).

The compositional spectrum of the volcanic rocks of the Campi Flegrei ranges from shoshonitic basalts to predominantly trachytes and phonolites (Di Girolamo et al., 1984; Rosi and Sbrana, 1987; D'Antonio et al., 1999).

\subsection{Ground deformation in the Pozzuoli area}

Evidences of a significant ground deformation of the central part of the NYT caldera occurred before 4 ka BP have been long documented in the area of Pozzuoli (Cinque et al., 1985; Amore et al., 1988; Orsi et al., 1996; Di Vito et al., 1999; Isaia et al., 2009). An uplifted coastal sector of the Pozzuoli Bay is exposed onland at the marine terrace called "La Starza", at 30 to $55 \mathrm{~m}$ above sea level (a.s.l.) (Fig. 1). The youngest marine deposits nowadays exposed at La Starza display a maximum elevation of $\sim 30 \mathrm{~m}$ a.s.l. and were originally deposited in water depth of 30 to $50 \mathrm{~m}$ b.s.l. (Amore et al., 1988). Accordingly, the total uplift at La Starza, onland, can be estimated in the order of 60-80 m.

Archaeological remains of Roman age, nowadays found at a water depth of $\sim 10 \mathrm{~m}$ along the western coast of the Pozzuoli Bay (Dvorak and Mastrolorenzo, 1991; Orsi et al., 1996; Passaro et al., 2012) indicate that the entire area underwent subsidence since Roman time. The relatively long post-Roman subsidence phase was interrupted at least once in the Middle Ages, and then followed by uplift that started at least 40 years before the 1538 Monte Nuovo eruption.

Recent ground deformation documented in the Pozzuoli area was accompanied by two bradyseismic crises occurred in 1970-71 and $1982-84$, with a cumulative ground uplift of $3.5 \mathrm{~m}$ in 15 years and maximum uplift rates of $100 \mathrm{~cm} /$ year in the period 1983-1984 (Berrino et al., 1984; Dvorak and Berrino, 1991; De Natale et al., 2001; Battaglia et al., 2006). After 1984, the ground slowly subsided until 2004-2005, when a new of deformation phase and enhanced hydrothermalism started (Troise et al., 2007), with $\sim 0.10 \mathrm{~m}$ of uplift at the end of 2013.

\subsection{The Pozzuoli Bay}

The Pozzuoli Bay is a minor inlet of the Gulf of Naples (Fig. 1), characterized by a central depression with maximum water depth reaching $\sim 110 \mathrm{~m}$ b.s.l. and bounded seaward by submerged volcanic banks (De Pippo et al., 1984; Pescatore et al., 1984). The oldest stratigraphic units are relics of volcanic edifices associated with explosive activity older than $40 \mathrm{kyr}$, overlain by products of the Campania Ignimbrite (39 ka BP, De Vivo et al., 2001; Rolandi et al., 2003; Deino et al., 2004) and NYT eruptions. The sedimentary succession of the last $15 \mathrm{ky}$ is represented by marine epiclastic deposits interbedded with volcaniclastic layers (Milia, 1998, 1999, 2010; Milia and Torrente, 2000; Insinga et al., 2002; Milia and Giordano, 2002; Sacchi et al., 2009; Budillon et al., 2011), mostly deposited inside the NYT caldera collapse.

There is a general consensus regarding the location of major morpho-structural lineaments, mostly described in terms of NE-SW, EW and NW-SE trends (Fig. 1) (Pescatore et al., 1984; Di Vito et al., 1999; Milia and Torrente, 2000; Milia and Giordano, 2002; Milia et al., 2003; Bruno, 2004). Acocella et al. (2004) and Acocella (2010) have suggested that NE-SW transfer faults likely played an important role in controlling the evolution of volcanic activity at Campi Flegrei. On 


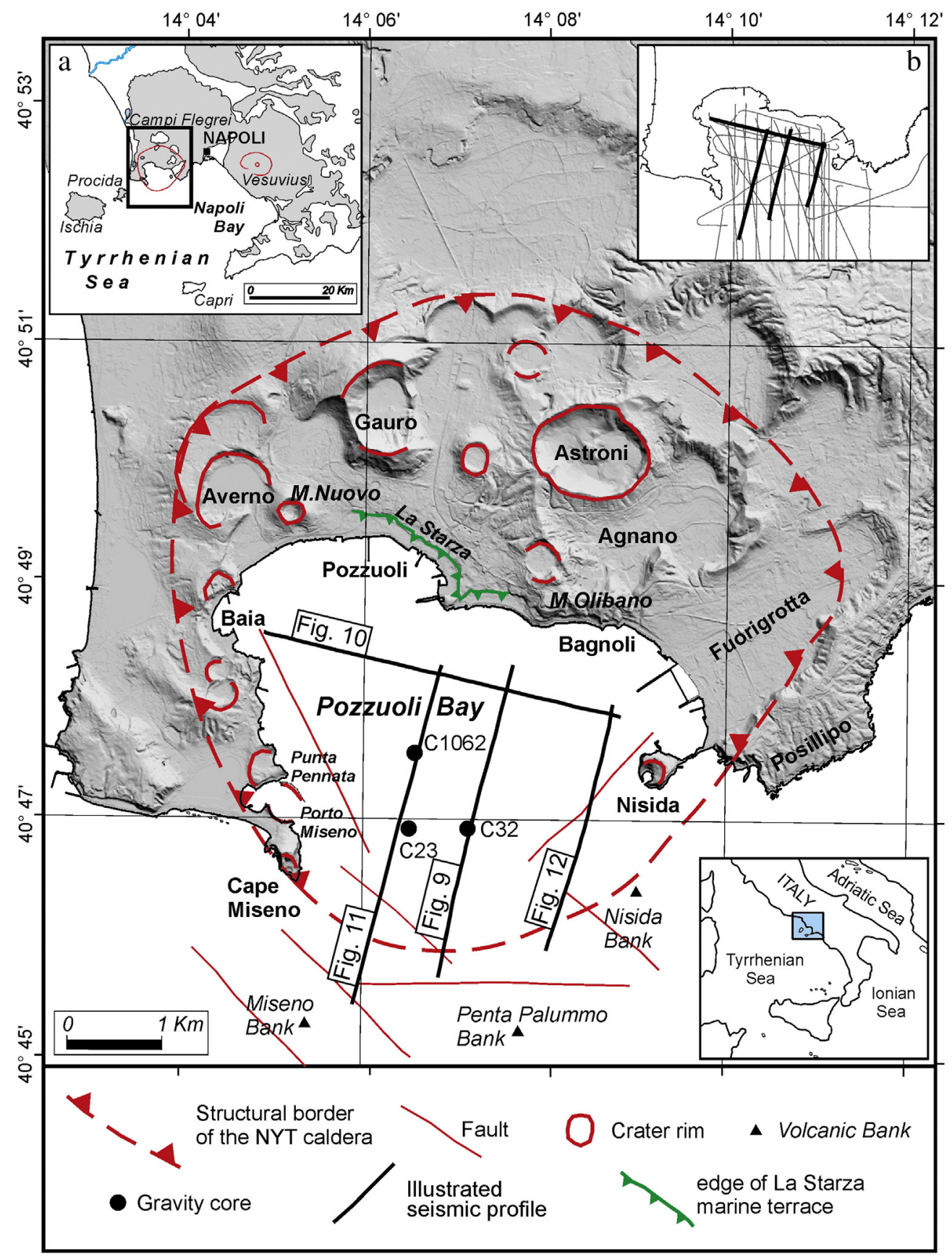

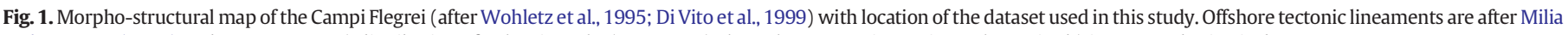
and Torrente (2003) and Bruno, 2004; a) distribution of volcanic rocks (grey areas) along the Campania continental margin; b) interpreted seismic dataset.

the basis of high-resolution multichannel seismic data acquired in the Pozzuoli Bay, Sacchi et al. (2009) have described the basic elements of the shallow structure of the NYT caldera.

\section{Materials and methods}

This study is based on integration of a) multibeam bathymetry, b) gravity core data and c) high-resolution single channel reflection seismics acquired by the IAMC-CNR in the Pozzuoli Bay between 2000 and 1010 . Swath bathymetry data provided support in the interpretation of the morphologic expression of the shallow structures and depositional environments. Seismic interpretation, calibrated with gravity core stratigraphy, was used to describe the main seismic stratigraphic units and understand the offshore stratal geometries and structures.
Tephra layers interbedded within the cored sequence have been characterized on the basis of lithological and chemical analyses and correlated to age-dated source events onland. The absolute ages obtained from tephrochronological analysis and AMS ${ }^{14} \mathrm{C}$ dating have been adopted, in turn, to construct an age-depth model for the cored succession and calibrate the seismic stratigraphic interpretation.

\subsection{Multibeam bathymetry}

The Digital Elevation Model (DEM) of the Pozzuoli Bay results from the integration of several datasets, mostly acquired by using Reson Seabat $(455 \mathrm{kHz})$ equipment in the range of 5 to $80 \mathrm{~m}$ below sea level (b.s.l.), and Reson Seabat $8111(100 \mathrm{kHz})$ for sectors deeper than $-80 \mathrm{~m}$ b.s.l. The acquisition system included a Gyro and a motion sensor for the real-time correction of vessel movements. A Differential 
Global Positioning System (DGPS) was used to track vessel position during the survey. Sound velocity profiles were recorded and applied in real-time during the acquisition every $8 \mathrm{~h}$.

Bathymetric data were processed by using the PDS2000 swath model editor tool for spike removal and merged with the PDS2000 grid editor model tool. Post-processed data from various sources were extracted as a regular grid with $10 \mathrm{~m}$ cell size. The hill-shaded GeoTIFF images of the combined datasets were created within Global Mapper software. The colour ramp for the GeoTIFF of the marine area was scaled between the sea level and the maximum measured water depth. Ambient lighting is from NNE $\left(30^{\circ}\right)$ at $50^{\circ}$ above the horizon, and vertical exaggeration is $4.8 \times$ (Fig. 2 ).

\subsection{Gravity cores}

Stratigraphic calibration of seismic records was provided by the detailed analysis of three gravity cores, (C1062, C23 and C32), collected in the Pozzuoli Bay at water depth of $~ 90$ to $103 \mathrm{~m}$ (Figs. 1-2). The length of recovered stratigraphic sections ranges from a total of $490 \mathrm{~cm}$ in core $\mathrm{C} 23$ to $265 \mathrm{~cm}$ in core C1062 and $390 \mathrm{~cm}$ in core C32 (Table 1).

Core samples were half-split, photographed and described at $\mathrm{cm}$-scale using a $10 \times$ lens. Microscope observation was conducted on

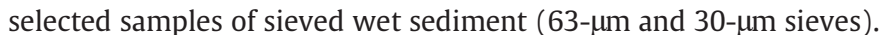
Sedimentological analysis included the recognition of major lithofacies associations, sedimentary structures, and grain-size analysis of the fraction $<63-\mu$ by laser diffractometry (Sympatec). Grain-size statistical parameters have been calculated according to the classic graphical equations of Folk and Ward (1957).

Paleontological analysis was conducted on $3 \mathrm{~cm}$ thick samples spaced every $10 \mathrm{~cm}$. Identification and ecological analysis of foraminifers and shell mollusks were made following Pérès and Picard (1964), Loeblich and Tappan (1988), and Sgarrella and Moncharmont Zei (1993).

\subsubsection{Chemical analysis of tephra samples}

Chemical analysis of tephra samples was performed both on glass concentrates (pumice and glass shards) and single glasses (pumice and shards). Glass concentrates were obtained by hand-picking under a microscope, avoiding grains with vesicles, crystalline intergrowth, and alteration. They were then rinsed in distilled water and cleaned with an ultrasonic probe.

Chemical composition in terms of major and trace element content on bulk sample (pumices) was obtained on pressed powder pellets by X-ray Fluorescence (XRF). Data were reduced following the method described by Melluso et al. (2005). Precision was higher than 3\% for major elements, $5 \%$ for $\mathrm{Zn}, \mathrm{Sr}, \mathrm{Zr}$ and Ba and better than $10 \%$ for the remaining trace elements. Weight loss on ignition (LOI) was determined by standard gravimetric procedures, after heating rock powders (previously dried at $\sim 150{ }^{\circ} \mathrm{C}$ in order to remove non-structural moisture $\mathrm{H}_{2} \mathrm{O}$ ) at $\sim 900{ }^{\circ} \mathrm{C}$ for $4 \mathrm{~h}$.

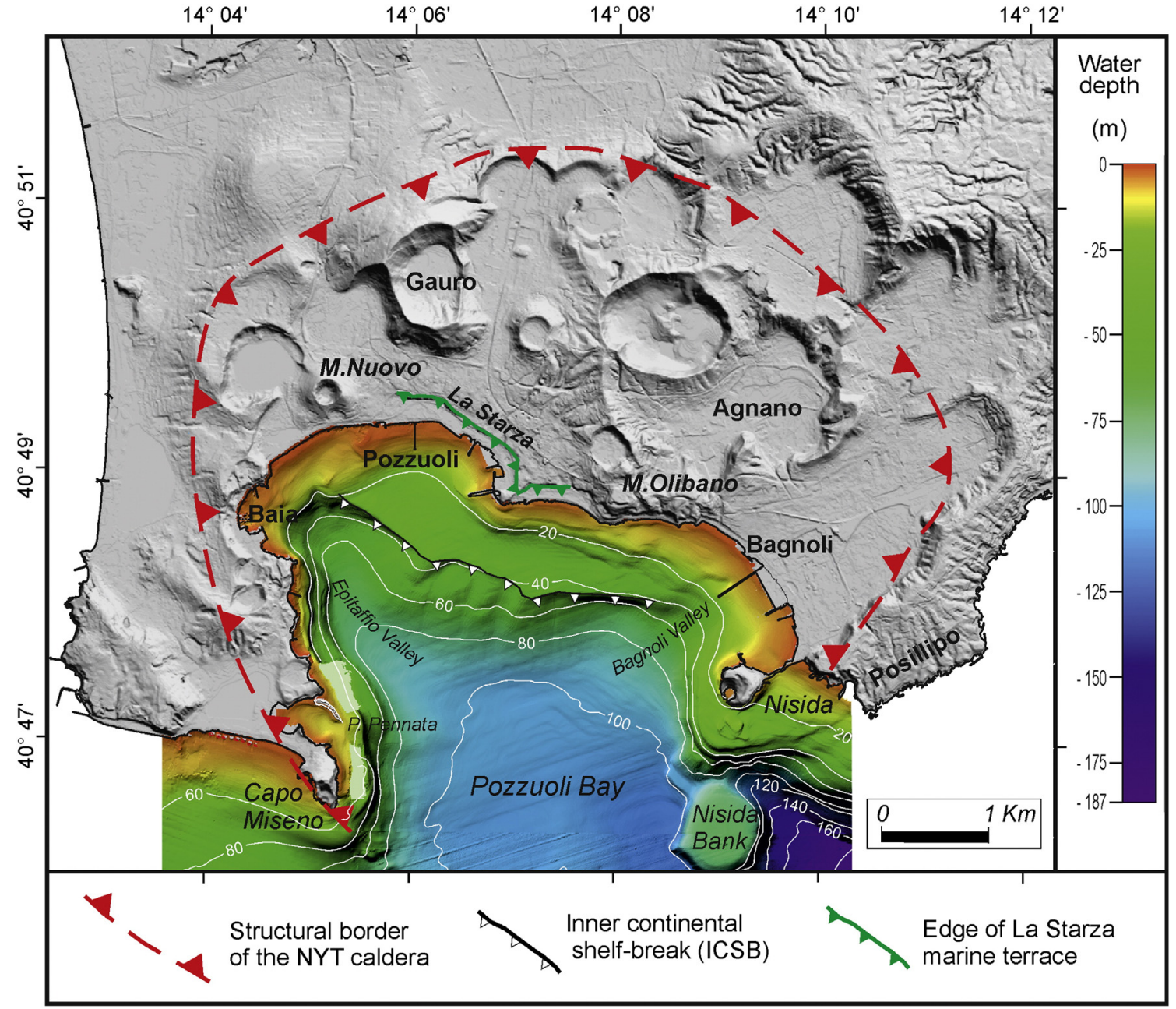

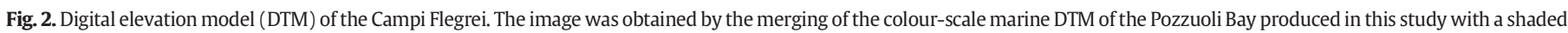
relief of the coastal area. 
Single glasses were mounted on epoxy resin, polished, and analysed in terms of major elements content with Energy Dispersive Spectrometry (EDS), utilizing an Oxford Instruments Microanalysis Unit, equipped with an INCA X-act detector and a JEOLJSM-5310. Operating conditions were: $15 \mathrm{kV}$ primary beam voltage, $45-55 \mu \mathrm{A}$ load current, $20 \mathrm{~mm}$ of work distance, spot size of $15-20 \mu \mathrm{m}$, and 50 s net acquisition time. Measurements were taken with an INCA X-stream pulse processor. Instrument calibration was based on international glass and mineral standards. Individual analyses of glass shards with total oxide sums lower than 95 wt.\% were excluded. The data selected were recalculated to 100 wt.\%.

\subsubsection{Radiocarbon dating}

Radiocarbon $\left({ }^{14} \mathrm{C}\right.$ AMS $)$ dating was performed using a system based on a 9SDH-2-Pelletron accelerator with a maximum terminal voltage of $3 \mathrm{MV}$ (Terrasi et al., 2007). The concentration of $\delta^{13} \mathrm{C}$ in each sample was measured using an elemental analyser (ThermoFinnigan EA 1112) coupled with an Isotope Ratio Mass Spectrometer (ThermoFinnigan Deltaplus). Samples were pre-treated in accordance with the procedures reported by Hoefs (1987), Vogel et al. (1984) and Passariello et al. (2007).

\subsection{High-resolution reflection seismics}

Seismic data include over $600 \mathrm{~km}$ of high-resolution (Geo-Source Sparker) and very high-resolution (Sub-bottom Chirp) single channel reflection seismic profiles acquired in the Pozzuoli Bay between 2007 and 2013. Profiles are mostly oriented in the NNW-SSE to NNE-SSW directions, with tie by lines acquired in a WNW-ESE direction (Figs. 1-2).

The Sub-Bottom Chirp profiler operated with a 16 transducer Benthos Chirp II system in a wide frequency band $(2-7 \mathrm{kHz})$, with a long pulse (20-30 ms). Signal penetration was exceeding $50 \mathrm{~ms}$, two-way time (twt) in the deeper sector of the bay.

Sparker data were acquired using a $1 \mathrm{~kJ}$ power supply with a multi-tip sparker array, a ringing-free system operating with a shot rate of $1.5 \mathrm{~s}$, and a base frequency of $\sim 800 \mathrm{~Hz}$. Data were recorded using a single channel streamer with an active section of $2.8 \mathrm{~m}$, containing seven highresolution hydrophones, for $1.3 \mathrm{~s}$ twt at a $10 \mathrm{kHz}(0.1 \mathrm{~ms})$ sampling rate. Navigation was controlled by a DGPS system.

The processing of sparker data was performed using the Geo-Suite AllWorks software package, and running a routine of the following mathematical operators: a) spherical divergence correction, b) bandpass (300-2000 Hz) filter, c) swell filter, d) traces mixing, e) predictive deconvolution, f) time varying gain and g) muting of water column. Signal penetration was found to exceed $500 \mathrm{~ms}$ (twt). Vertical resolution reached up to $0.5 \mathrm{~m}$ near the seafloor.

Processing of seismic data included conversion from time to depth of the vertical scale of seismic sections. Correlation between stratigraphic units and seismic velocities was based on analysis of seismic facies and lithostratigraphic data (Rosi and Sbrana, 1987; Di Vito et al., 1999). Depth-converted sections were plotted with vertical exaggeration of $6 \times$, to better display the internal architecture of stratigraphic units.

\section{Data and results}

\subsection{Morpho-bathymetry of the Pozzuoli Bay}

The surveyed area extends approximately $30 \mathrm{~km}^{2}$. Bathymetric profiles, drawn perpendicular to the coastline and down to a water depth of $\sim 110 \mathrm{~m}$, show the main characteristics of the inner shelf/slope/basin morphology (Fig. 3). The width of the inner continental shelf (ICS) (0-40 m b.s.l.) of the Pozzuoli Bay varies significantly, from $1.8 \mathrm{~km}$ west of Pozzuoli (Profile 1, in Fig. 3) and $1.6 \mathrm{~km}$ between Bagnoli and Nisida to less than a few hundred metres at its western side (Baia). The inner sector of the continental shelf is also characterized by a series of stepped terraced surfaces located at water depth of $10 \mathrm{~m}, 25 \mathrm{~m}$ and $35 \mathrm{~m}$ over a distance of $\sim 4 \mathrm{~km}$ (Profiles 2 and 3 in Fig. 3). Terraced areas correspond either to erosional features or toplap/offlap surfaces of local prograding wedges and are likely the result of the dynamic equilibrium between seafloor erosion at the base of the storm waves and the sediment supply from the coastline during the Holocene rise of sea level.

A remarkable morphological feature is represented by a pronounced break in the ICS profile (Figs. 2 and 4), elongated in a WNW-ESE direction, ranging water depths from $\sim 25$ to $\sim 45 \mathrm{~m}$ b.s.l. towards ESE. A slightly convex-upward area, with average slope of less than $3^{\circ}$, connects the ICS break (ICSB) to the deeper part of the bay (Profiles 4 and 5 Fig. 3), where water depth reaches $\sim 115 \mathrm{~m}$ (Profile 6, Fig. 3). At the foot of the ICS slope, the transition between these domains occurs along a semi-circular depression extending in NNW-SSE (Epitaffio Valley) and NE-SW (Bagnoli Valley) directions (T in Fig. 3). Evidence of linear erosion, locally associated with seafloor instability, can be found both along the thalweg of Epitaffio and Bagnoli Valleys and on the southern slope of the ICS (Profile 4, Fig. 3). The average slope of sea floor increases to $8.5^{\circ}$ towards the eastern sector of the bay, close to Nisida Island, and up to $12^{\circ}$ in the western sector, close to Baia (Profile 4, Fig. 3).

\subsection{Gravity core stratigraphy}

Sedimentological analysis of cores C1062, C23 and C32 indicates that the stratigraphic succession sampled in the Pozzuoli Bay is represented by a homogeneous grey mud, made of bioturbated sandy clayey silt with interbedded layers/lenses rich in bioclasts and/or volcaniclasts and three tephra layers (Fig. 4). The sandy fraction is generally fine to very fine grained and consists of volcaniclasts (pumices and scoriae, loose crystals of feldspar, biotite, pyroxene) and bioclasts (benthonic and planktonic forams, mollusc shells, pteropods and ostracods).

Differences in macro and microfossil contents permit distinguishing a) an infralittoral assemblage characterized by specimens of Cardium edule Linnaeus, Natica hebraea (Martyn), Crisia eburnea (Linnaeus) and Elphidium punctatum (Terquem), Ammonia beccarii (Linneo), grading towards the upper part to b) a circalittoral assemblage characterized by Nucula nucleus (Linneo), Turritella communis Risso, Tellina nitida Poli, Corbula gibba (Olivi), Spiratella bulimoides d'Orbigny and Uvigerina mediterranea Hofker, Melonis barleanum (Williamson), Bolivina alata (Seguenza), Amphicorina scalaris (Batsch) (Pérès and Picard, 1964; Amore et al., 1988; Sgarrella and Moncharmont Zei, 1993).

Three tephra layers were detected within the cored succession and labelled from top to bottom as PB1, PB2 and PB3 (Table 1 and Fig. 4). Tephra PB1 is a 1-3 cm thick, primary fall deposit occurring at 56, 86 and $50 \mathrm{~cm}$ below sea floor (b.s.f.) in cores C32, C23, and C1062, respectively. It displays a sharp base and is made of medium-grained, subangular pumice lapilli with rare fragments of Posidonia oceanica (L.) Delile. Pumice fragments are well vesiculated and completely aphyric.

PB2 is a 2-3 cm thick cryptotephra, found at 190,180 and $118 \mathrm{~cm}$ b.s.f. in cores C23, C32 and C1062, respectively. The deposit is represented by normally graded, medium to fine-grained ash, mostly composed of lithics, some of them leucite-bearing, loose crystals of feldspars, biotite and clinopyroxenes, very rare scoriae and honey coloured glass shards with thin-walled bubble junction morphology. Carbonate xenolites and bioclasts also occur. The layer displays a sharp lower boundary and parallel lamination at its base and a gradual transition to marine epiclastic deposits towards the top. The deposit is interpreted as a result of partial in-situ reworking (e.g. bioturbation) of the primary pyroclastic fall.

Tephra PB3 forms a decimetre thick layer at the base of the cored succession. It displays a thickness of $60 \mathrm{~cm}$ in cores C32 and C1062 and $50 \mathrm{~cm}$ in core C23. The deposit is characterized by consolidated, medium to fine ash mostly made of feldspars (sanidine), rare scoriae, pumices and glass shards overlaid by a $2 \mathrm{~cm}$ thick pumice lapilli layer. 

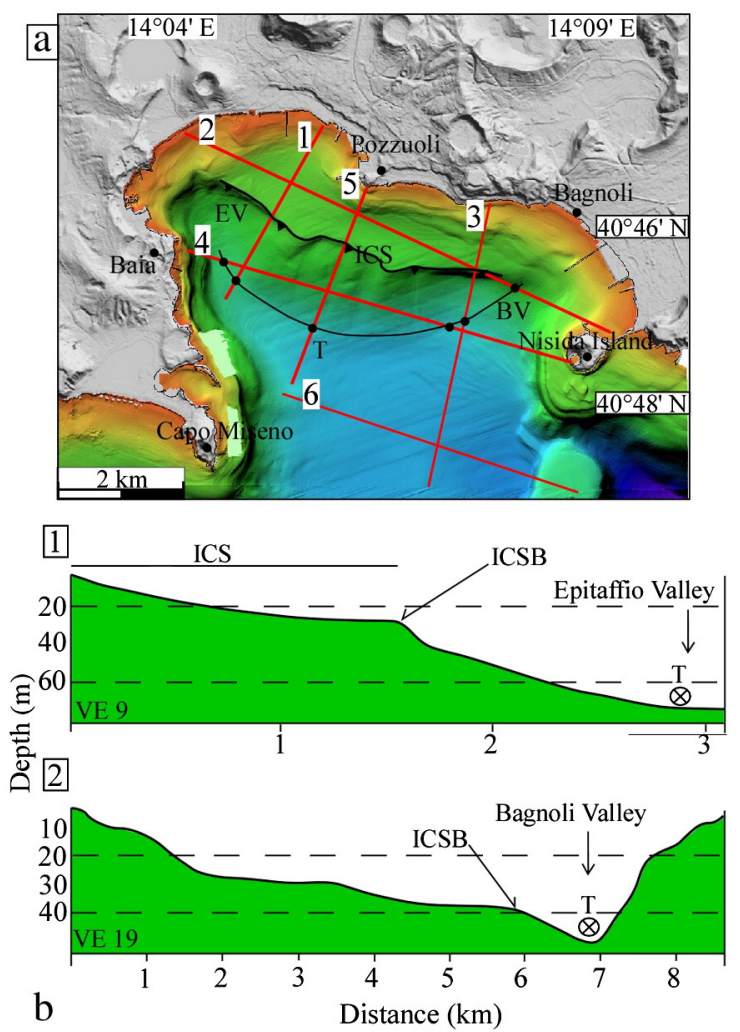
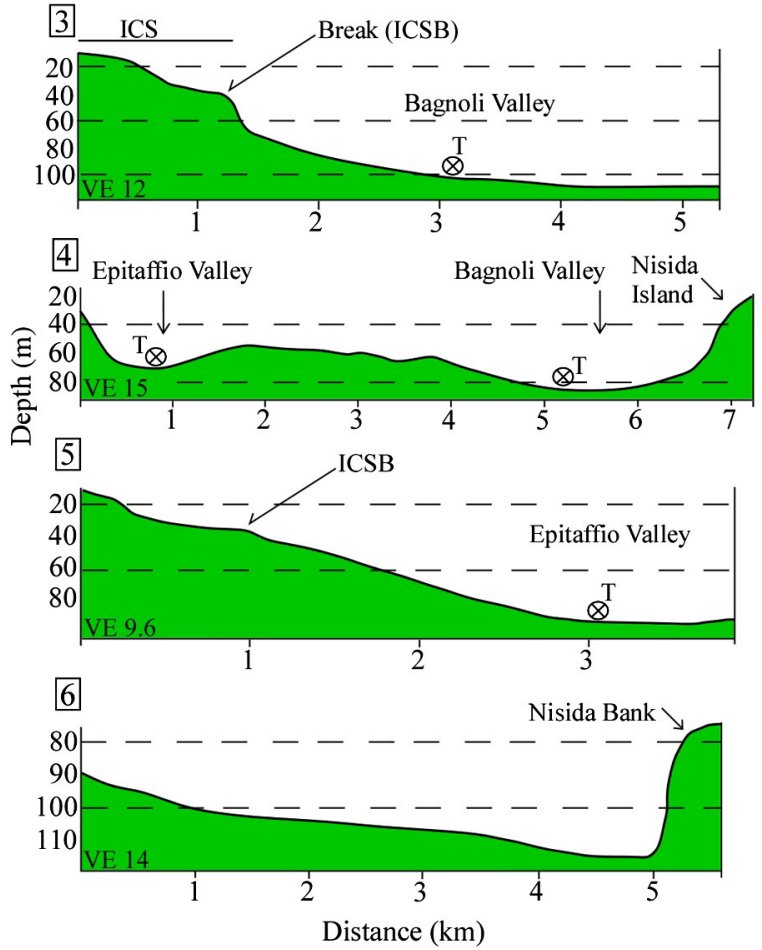

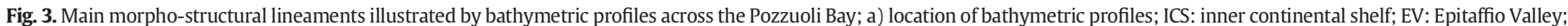
BV: Bagnoli Valley; T: Thalweg of the EV-BV morpho-structural depression; ICSB: inner continental shelf break; VE: vertical exaggeration.

The upper part of the layer includes sparse bioclasts that suggest the occurrence of in-situ reworking.

\subsubsection{Classification of tephra layers}

The results of chemical analyses conducted on tephras are reported in Tables 2 and 3. According to the Total Alkali/Silica (TAS) classification diagram (Fig. 5), tephras PB1 and PB3 show a phonolitic composition, very close to the boundary with the trachyte field. Although the bulkrock analysis generally reflects a composition of glass and crystal mixture, in the case of tephra PB1, the aphyric texture of the separated pumices was expected to yield reliable results on the composition of the source magma (Table 3). Cryptotephra PB2 shows a dominant phonolitic population with silica values ranging from $55.22 \mathrm{wt}$.\% to $55.63 \mathrm{wt} . \%$ and alkali values from $10.82 \mathrm{wt}$.\% to $14.75 \mathrm{wt} . \%$ (Table 2). A minor distinctive trachytic fraction also occurs within the deposit.

The compositions of the analysed tephras are typical of the slightly undersaturated potassic products (PB1 and PB3) erupted at Campi Flegrei during the last $15 \mathrm{kyr}$ (D'Antonio et al., 1999; Melluso et al., 2012 and references therein) and the highly undersaturated potassic products (PB2) erupted at Somma-Vesuvius during the last $3 \mathrm{kyr}$ (Santacroce et al., 2008 and references therein), (Fig. 5).

\subsubsection{Results of radiocarbon dating}

An AMS ${ }^{14} \mathrm{C}$ age determination was performed on a mollusc shell (Cardium sp) sampled within the upper part of tephra PB3, in core C32 at $348 \mathrm{~cm}$ b.s.f. The obtained conventional radiocarbon age was of $3994 \pm 39$ years BP which is consistent with the stratigraphic position of the analysed sample. This result was converted into a calendar age of $3904 \pm 60$ years BP $(1 \sigma)$ using OxCal 4.2 software (Bronk Ramsey, 2009) and INTCAL013 dataset (Reimer et al., 2013), with a marine reservoir correction of ca.400 years (Siani et al., 2000).

\subsection{Definition of seismic units}

Seven seismic units labelled from bottom to top as NYT, RC, U3, T1, EM1, T2, and EM2 were identified on seismic lines on the basis of seismic characters, such as amplitude, reflection continuity, geometry, and frequency and shape of reflections (Fig. 6).

Unit NYT is characterized by discontinuous reflections with varying amplitude and frequency and it represents the acoustic basement for the sparker source in the study area (Figs. 6b and 7c). Unit RC can be subdivided into two subunits on the basis of seismic facies, namely RC.1 and RC.2 (Fig. 7b). Subunit RC.1 shows irregular to chaotic, discontinuous, and moderate to high-amplitude reflections and it is locally offset by a series of normal faults that often cut down into the underlying NYT unit. The lower boundary of subunit RC.1 and the geometry of its internal reflections are partially obscured by the occurrence of pore fluids that locally modify reflection amplitudes. Subunit RC.2 typically displays parallel, continuous and moderate to locally low-amplitude, high-frequency reflections. It can be defined above the flanks of an antiformal structure towards in the central-northern part of the Pozzuoli Bay.

Unit U3 conformably overlies the top of unit RC and is bounded at the top by a high-amplitude, continuous reflector. It is characterized by discontinuous to locally continuous, medium-amplitude reflections with a wedge-shaped geometry and well-defined edge, (Figs. 6, 7b and c).

The uppermost part of the sequence is represented by units T1, EM1, T2 and EM2 (Fig. 6). Unit T1 is characterized by chaotic to reflection-free seismic facies bounded at the top by a high-amplitude and well-defined continuous reflectors (Figs. 6 and 7d). Unit T1 is overlain by wellstratified deposits (unit EM1), characterized by parallel, medium to low-amplitude, locally continuous reflections (Fig. 6). Unit T2 is characterized by moderate to high-amplitude, locally discontinuous reflections, often associated with disrupted or chaotic, high-amplitude reflectors 


\section{Gravity core C23}

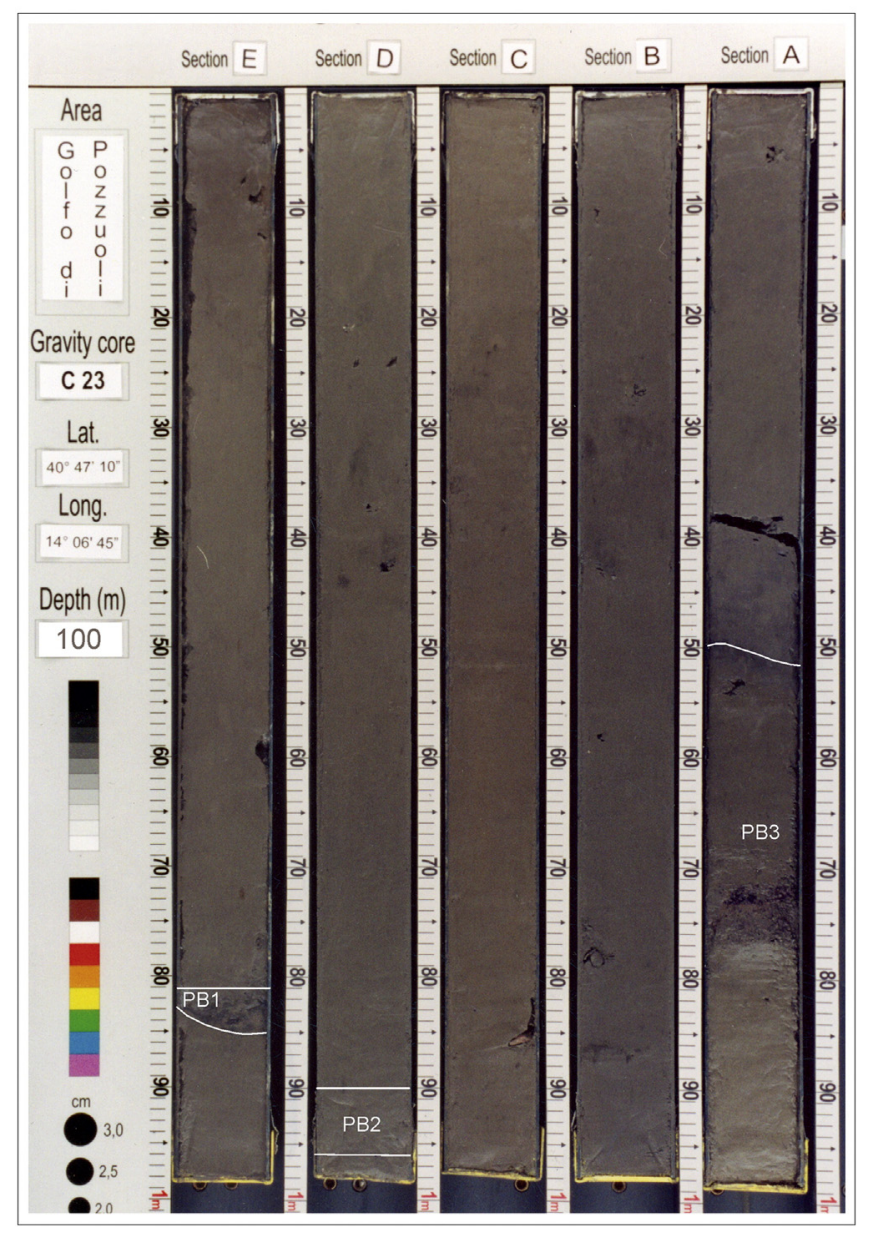

Fig. 4. Photograph of $\mathrm{C} 23$ core splits. Labels $\mathrm{E}$ to $\mathrm{A}$ denote core sections from top ( $0 \mathrm{~cm}$ b.s.f.) to bottom (490 cm b.s.f.). Tephra layers PB1 and PB3 and cryptotephra PB2 are indicated.

(Figs. 6 and 7d). Its lower boundary is represented by a high-amplitude and well-defined continuous reflector. The unit is bounded at the top by continuous, high-amplitude, hummocky reflectors. Landward, onlap reflectors overlay the top of unit EM1.

Unit EM2 is characterized by parallel, medium to low-amplitude, locally continuous reflections (Figs. 6 and 7d). The top of Unit EM2 is represented by the seafloor while the lower boundary corresponds to a high-amplitude, strong continuous reflector that can be correlated to tephra PB3. A high-amplitude, well-defined, continuous reflector almost parallel to the seafloor, can be identified inside unit EM2. Calibration of this reflector with the gravity core stratigraphy indicates a correlation with tephra PB2 (Fig. 7d).

Two subunits, namely EM2.C and EM2.H, can be defined in the inner shelf area, corresponding to the north-eastern part of the bay, (Fig. 7e).
Subunit EM2.C displays a wedge shape and well-defined lower boundary. It is internally characterized by low-amplitude and obliquetangential, prograding reflectors with medium lateral continuity. The base of the unit corresponds to a downlap surface, while its upper boundary is characterized by toplap/offlap stratal terminations. Subunit EM2.H exhibits a wedge-shaped geometry, with laterally continuous reflectors characterized by a low-angle prograding of sedimentary layers. Towards the upper part of the continental shelf, the reflectors of subunit EM2.H downlap over an erosional surface that truncates the underlying units (Fig. 7e).

\section{Interpretation}

\subsection{Integrated stratigraphy of the cored succession}

Facies interpretation supported by analysis of grain-size statistical parameters indicates that gravity cores C1062, C32 and C23 have sampled a relatively monotonous succession of bioturbated mud, with occasional intercalations of coarser layers, mostly represented by sandy silt rich in bioclasts and/or volcaniclasts, along with three tephra layers (PB1 to PB3) (Fig. 8). The lithofacies associations can be readily correlated among the stratigraphic succession of the three cores and suggest a deepening-upward trend within the sequence (Fig. 8). The fossil assemblages, coupled with facies analysis, indicate a transition from infralittoral to circalittoral environment occurring between tephras PB3 and PB2 at depth of $140 \mathrm{~cm}$ b.s.f. (C1062) to $340 \mathrm{~cm}$ b.s.f. (C23) (Fig. 8).

\subsubsection{Correlation of tephra layers with source events}

Once the source area for the tephra deposits was recognized, along with the integrated information on their chemical composition, stratigraphic position and lithology, a correlation with age-dated events on land was attempted (Figs. 5 and 8). Tephra PB1 is characterized by a $\mathrm{K}_{2} \mathrm{O} / \mathrm{Na}_{2} \mathrm{O} \sim 1$ with $\mathrm{SiO}_{2}$ concentration at $\sim 60$ wt.\% and a high content of incompatible elements, such as $\mathrm{Zr}$ (897 ppm) and $\mathrm{Nb}$ (141 ppm) (Table 3). This distinctive composition indicates an affinity of tephra PB1 to the very last phase of Campi Flegrei activity that was characterized by more evolved products (D'Antonio et al., 1999). The chemistry and stratigraphic position of the deposit suggest a correlation of tephra PB1 with the Monte Nuovo eruption that which represents the last event occurred at Campi Flegrei (1538 A.D.).

The phonolitic composition, along with its lithofacies (e.g. the occurrence of carbonate and leucite-bearing lithics) and the stratigraphic position, allows a correlation of cryptotephra PB2 with the 79 A.D. products of Somma-Vesuvius (Lirer et al., 1973). The occurrence of parallel lamination at the base of the deposit suggest possible syn-eruptive reworking as already described for this marker tephra in the Naples Bay (Sacchi et al., 2005; Milia et al., 2008). The minor trachytic population of cryptotephra PB2 may also indicate reworking and partial amalgamation with coeval products of Ischia island activity such as the Cretaio event ( 60 A.D.; Orsi et al., 1992), found elsewhere off the Campania margin (de Alteriis et al., 2010).

Glasses from tephra PB3 are characterized by $\mathrm{SiO}_{2}$ concentrations ranging from $\sim 58 \%$ to $\sim 60 \%$ and an alkali ratio from 2.44 to 1.50 with

Table 1

Summary gravity core data.

\begin{tabular}{|c|c|c|c|c|c|c|c|c|c|c|c|c|c|}
\hline \multirow[t]{3}{*}{ Core no } & \multirow{3}{*}{$\begin{array}{l}\text { Latitude N } \\
\operatorname{deg}\left({ }^{\circ}\right)\end{array}$} & \multirow[t]{3}{*}{ Longitude $\mathrm{E}$ deg $^{\circ}$} & \multirow[t]{3}{*}{ Water depth (m) } & \multirow{3}{*}{$\begin{array}{l}\text { Core lenght } \\
(\mathrm{cm})\end{array}$} & \multicolumn{3}{|c|}{ Tephra PB1 } & \multicolumn{3}{|c|}{ Tephra PB2 } & \multicolumn{3}{|c|}{ Tephra PB3 } \\
\hline & & & & & \multicolumn{2}{|c|}{$\begin{array}{l}\text { Depth below } \\
\text { seafloor } \\
(\mathrm{cm})\end{array}$} & \multirow[t]{2}{*}{$\begin{array}{l}\text { Thickness } \\
(\mathrm{cm})\end{array}$} & \multicolumn{2}{|c|}{$\begin{array}{l}\text { Depth below } \\
\text { seafloor } \\
(\mathrm{cm})\end{array}$} & \multirow[t]{2}{*}{$\begin{array}{l}\text { Thickness } \\
(\mathrm{cm})\end{array}$} & \multicolumn{2}{|c|}{$\begin{array}{l}\text { Depth below } \\
\text { seafloor } \\
(\mathrm{cm})\end{array}$} & \multirow[t]{2}{*}{$\begin{array}{l}\text { Thickness } \\
(\mathrm{cm})\end{array}$} \\
\hline & & & & & Bottom & Top & & Bottom & Top & & Bottom & Top & \\
\hline C 23 & $40^{\circ} 47^{\prime} 10^{\prime \prime}$ & $14^{\circ} 06^{\prime} 45^{\prime \prime}$ & 103.0 & 490 & 404 & 86 & 4 & 295 & 195 & 5 & - & 443 & 47 \\
\hline C 32 & $40^{\circ} 47^{\prime} 10^{\prime \prime}$ & $14^{\circ} 07^{\prime} 27^{\prime \prime}$ & 103.0 & 382 & 324 & 58 & 4 & 196 & 186 & 5 & - & 324 & 60 \\
\hline C 1062 & $40^{\circ} 47^{\prime} 54^{\prime \prime}$ & $14^{\circ} 06^{\prime} 48^{\prime \prime}$ & 90.6 & 265 & 215 & 50 & 3 & 147 & 118 & 3 & - & 202 & 63 \\
\hline
\end{tabular}


Table 2

Major element composition (wt.\%) of glasses from cryptotephra PB2 and tephraPB3. All analyses recalculated water-free to 100 . The original total is reported. alk: Na2O + K2O.

\begin{tabular}{|c|c|c|c|c|c|c|c|c|c|c|c|c|c|c|c|c|c|c|c|c|c|c|}
\hline \multicolumn{23}{|c|}{ Tephra PB2 } \\
\hline \multicolumn{12}{|c|}{ Core/sample } & \multicolumn{11}{|l|}{ C32/B60a } \\
\hline $\mathrm{SiO}_{2}$ & 55.35 & \multicolumn{2}{|r|}{55.24} & 55.63 & 54.57 & \multicolumn{2}{|c|}{54.84} & 55.58 & 55.52 & 55.26 & \multicolumn{2}{|r|}{55.30} & 55.17 & 54.95 & \multicolumn{2}{|c|}{57.03} & 55.22 & 61.59 & \multicolumn{2}{|c|}{61.96} & 62.51 & 63.62 \\
\hline $\mathrm{TiO}_{2}$ & 0.31 & \multicolumn{2}{|r|}{0.53} & 0.25 & 0.33 & \multicolumn{2}{|c|}{0.39} & 0.31 & 0.73 & 0.51 & & 0.59 & 0.44 & 0.24 & \multicolumn{2}{|c|}{0.16} & 0.55 & 0.30 & \multicolumn{2}{|c|}{0.73} & 0.75 & 0.49 \\
\hline $\mathrm{Al}_{2} \mathrm{O}_{3}$ & 20.73 & \multicolumn{2}{|r|}{21.15} & 20.86 & 21.10 & \multicolumn{2}{|c|}{22.55} & 20.60 & 20.74 & 20.88 & \multicolumn{2}{|r|}{21.18} & 21.24 & 20.73 & \multicolumn{2}{|c|}{21.81} & 21.19 & 18.08 & \multicolumn{2}{|c|}{18.67} & 18.20 & 17.60 \\
\hline $\mathrm{FeO}$ & 3.88 & \multicolumn{2}{|r|}{3.79} & 4.09 & 3.78 & \multicolumn{2}{|c|}{2.17} & 4.01 & 3.26 & 3.18 & & 3.24 & 3.30 & 3.91 & \multicolumn{2}{|c|}{3.41} & 3.00 & 3.14 & & & 2.54 & 2.30 \\
\hline $\mathrm{MnO}$ & 0.00 & & 0.25 & 0.00 & 0.00 & 0. & & 0.40 & 0.13 & 0.27 & & 0.00 & 0.27 & 0.08 & & & 0.16 & 0.30 & & & 0.06 & 0.04 \\
\hline MgO & 0.24 & & 0.22 & 0.33 & 0.49 & 0. & & 0.33 & 0.36 & 0.28 & & 0.41 & 0.34 & 0.19 & & & 0.34 & 0.58 & & & 0.25 & 0.35 \\
\hline $\mathrm{CaO}$ & 3.75 & & 4.08 & 4.78 & 4.77 & 3. & & 4.01 & 3.93 & 3.10 & & 4.39 & 4.52 & 3.98 & & & 4.30 & 2.16 & & & 1.67 & 1.84 \\
\hline $\mathrm{Na}_{2} \mathrm{O}$ & 6.70 & & 6.35 & 6.56 & 5.87 & 7. & & 6.45 & 6.67 & 7.53 & & 7.66 & 6.31 & 7.22 & & & 6.72 & 3.73 & & & 6.21 & 5.07 \\
\hline $\mathrm{K}_{2} \mathrm{O}$ & 8.05 & & 6.83 & 6.65 & 8.22 & 7. & & 7.20 & 7.82 & 7.35 & & 6.31 & 7.04 & 7.48 & & & 7.31 & 9.08 & & & 7.28 & 7.39 \\
\hline $\mathrm{P}_{2} \mathrm{O}_{5}$ & 0.00 & & 0.32 & 0.00 & 0.07 & 0. & & 0.23 & 0.00 & 0.31 & & 0.00 & 0.00 & 0.23 & & & 0.13 & 0.28 & & & 0.16 & 0.26 \\
\hline $\mathrm{F}$ & 0.23 & & 0.32 & 0.08 & 0.00 & 0. & & 0.00 & 0.00 & 0.50 & & 0.13 & 0.55 & 0.09 & & & 0.42 & 0.00 & & & 0.00 & 0.30 \\
\hline $\mathrm{Cl}$ & 0.77 & & 0.92 & 0.76 & 0.81 & & & 0.89 & 0.85 & 0.83 & & 0.80 & 0.82 & 0.90 & & & 0.66 & 0.75 & & & 0.35 & 0.75 \\
\hline Total & 96.25 & & 96.70 & 96.40 & 96.92 & 99. & & 97.32 & 97.49 & 97.97 & & 96.95 & 97.13 & 97.76 & 100 & & 99.72 & 96.14 & 100. & & 99.50 & 96.77 \\
\hline Alk & 14.75 & & 13.17 & 13.21 & 14.09 & 15. & & 13.65 & 14.49 & 14.88 & & 13.97 & 13.35 & 14.70 & 10 & & 14.04 & 12.82 & 13. & & 13.49 & 12.46 \\
\hline Tephra & & & & & & & & & & & & & & & & & & & & & & \\
\hline Core/sc & & & & $\mathrm{C} 23 / 46$ & & & & & $\mathrm{C} 23 / 46$ & & & & & & & & & & & & & \\
\hline $\mathrm{SiO}_{2}$ & 58.30 & 58.86 & 58.59 & 58.64 & 58.97 & 58.98 & 59.42 & 58.24 & 58.78 & 57.69 & 58.01 & 57.14 & 57.46 & 59.22 & 58.97 & 58.91 & 58.38 & 58.01 & 58.30 & 57.68 & 58.04 & 57.51 \\
\hline $\mathrm{TiO}_{2}$ & 0.38 & 0.36 & 0.58 & 0.63 & 0.28 & 0.58 & 0.26 & 0.49 & 0.44 & 0.50 & 0.25 & 0.74 & 0.40 & 0.48 & 0.56 & 0.47 & 0.59 & 0.19 & 0.33 & 0.60 & 0.83 & 0.34 \\
\hline $\mathrm{Al}_{2} \mathrm{O}_{3}$ & 18.90 & 18.91 & 18.42 & 18.77 & 19.21 & 18.75 & 18.82 & 18.55 & 19.16 & 18.84 & 18.63 & 18.39 & 18.67 & 19.03 & 18.46 & 18.72 & 18.29 & 18.46 & 19.28 & 18.46 & 19.44 & 18.20 \\
\hline $\mathrm{FeO}$ & 4.06 & 3.99 & 4.25 & 4.04 & 4.19 & 4.20 & 3.66 & 3.92 & 3.64 & 3.01 & 3.57 & 3.61 & 3.82 & 4.23 & 3.81 & 3.10 & 3.20 & 3.78 & 4.02 & 4.12 & 3.20 & 4.07 \\
\hline $\mathrm{MnO}$ & 0.36 & 0.21 & 0.00 & 0.15 & 0.02 & 0.00 & 0.06 & 0.32 & 0.00 & 0.00 & 0.34 & 0.08 & 0.28 & 0.18 & 0.00 & 0.00 & 0.03 & 0.01 & 0.02 & 0.25 & 0.00 & 0.00 \\
\hline $\mathrm{MgO}$ & 0.58 & 0.77 & 0.84 & 0.72 & 0.52 & 0.64 & 0.72 & 0.61 & 0.69 & 0.78 & 0.61 & 0.67 & 0.48 & 0.70 & 0.60 & 0.63 & 0.59 & 0.65 & 0.62 & 0.79 & 0.69 & 0.60 \\
\hline $\mathrm{CaO}$ & 2.96 & 2.90 & 3.20 & 2.60 & 2.15 & 2.82 & 3.29 & 3.01 & 2.46 & 3.05 & 2.86 & 2.80 & 2.36 & 2.78 & 2.38 & 2.99 & 2.89 & 2.73 & 2.56 & 2.76 & 2.98 & 2.75 \\
\hline $\mathrm{Na}_{2} \mathrm{O}$ & 4.62 & 4.86 & 3.91 & 4.47 & 5.68 & 4.25 & 4.67 & 4.51 & 5.35 & 4.14 & 4.35 & 4.04 & 4.43 & 4.12 & 4.25 & 4.25 & 4.25 & 4.31 & 4.30 & 4.22 & 4.46 & 4.37 \\
\hline $\mathrm{K}_{2} \mathrm{O}$ & 8.93 & 8.77 & 9.54 & 9.28 & 8.52 & 9.45 & 8.33 & 9.11 & 8.45 & 9.31 & 9.24 & 9.04 & 8.94 & 9.29 & 9.32 & 8.94 & 9.33 & 9.09 & 9.37 & 9.10 & 9.11 & 9.10 \\
\hline $\mathrm{P}_{2} \mathrm{O}_{5}$ & 0.40 & 0.00 & 0.04 & 0.26 & 0.00 & 0.00 & 0.24 & 0.29 & 0.14 & 0.18 & 0.13 & 0.13 & 0.44 & 0.18 & 0.03 & 0.20 & 0.08 & 0.00 & 0.23 & 0.10 & 0.00 & 0.39 \\
\hline $\mathrm{F}$ & 0.00 & 0.00 & 0.26 & 0.00 & 0.00 & 0.00 & 0.00 & 0.33 & 0.00 & 0.00 & 0.00 & 0.08 & 0.23 & 0.52 & 0.00 & 0.00 & 0.02 & 0.18 & 0.25 & 0.37 & 0.00 & 0.10 \\
\hline $\mathrm{Cl}$ & 0.66 & 0.72 & 0.57 & 0.63 & 0.64 & 0.71 & 0.68 & 0.60 & 0.62 & 0.62 & 0.65 & 0.65 & 0.75 & 0.65 & 0.66 & 0.50 & 0.63 & 0.65 & 0.62 & 0.68 & 0.76 & 0.73 \\
\hline Total & 99.90 & 96.98 & 96.34 & 97.78 & 99.51 & 97.99 & 98.08 & 99.39 & 99.48 & 97.95 & 98.30 & 97.36 & 98.25 & 101.37 & 98.61 & 98.31 & 98.29 & 98.03 & 99.90 & 99.14 & 99.44 & 98.14 \\
\hline Alk & 13.55 & 13.63 & 13.45 & 13.75 & 14.21 & 13.69 & 12.99 & 13.62 & 13.81 & 13.45 & 13.58 & 13.07 & 13.37 & 13.41 & 13.57 & 13.19 & 13.58 & 13.39 & 13.67 & 13.33 & 13.56 & 13.46 \\
\hline
\end{tabular}


Table 3

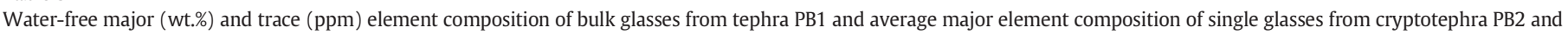

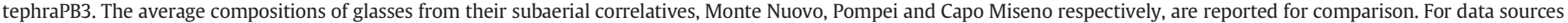
see Fig. 6; A.I.: molar (Na2O + K2O)/Al2O3; n: number of analyses; $\sigma$ : standard deviation (values in italics); p: pumice; gs: glass shard.

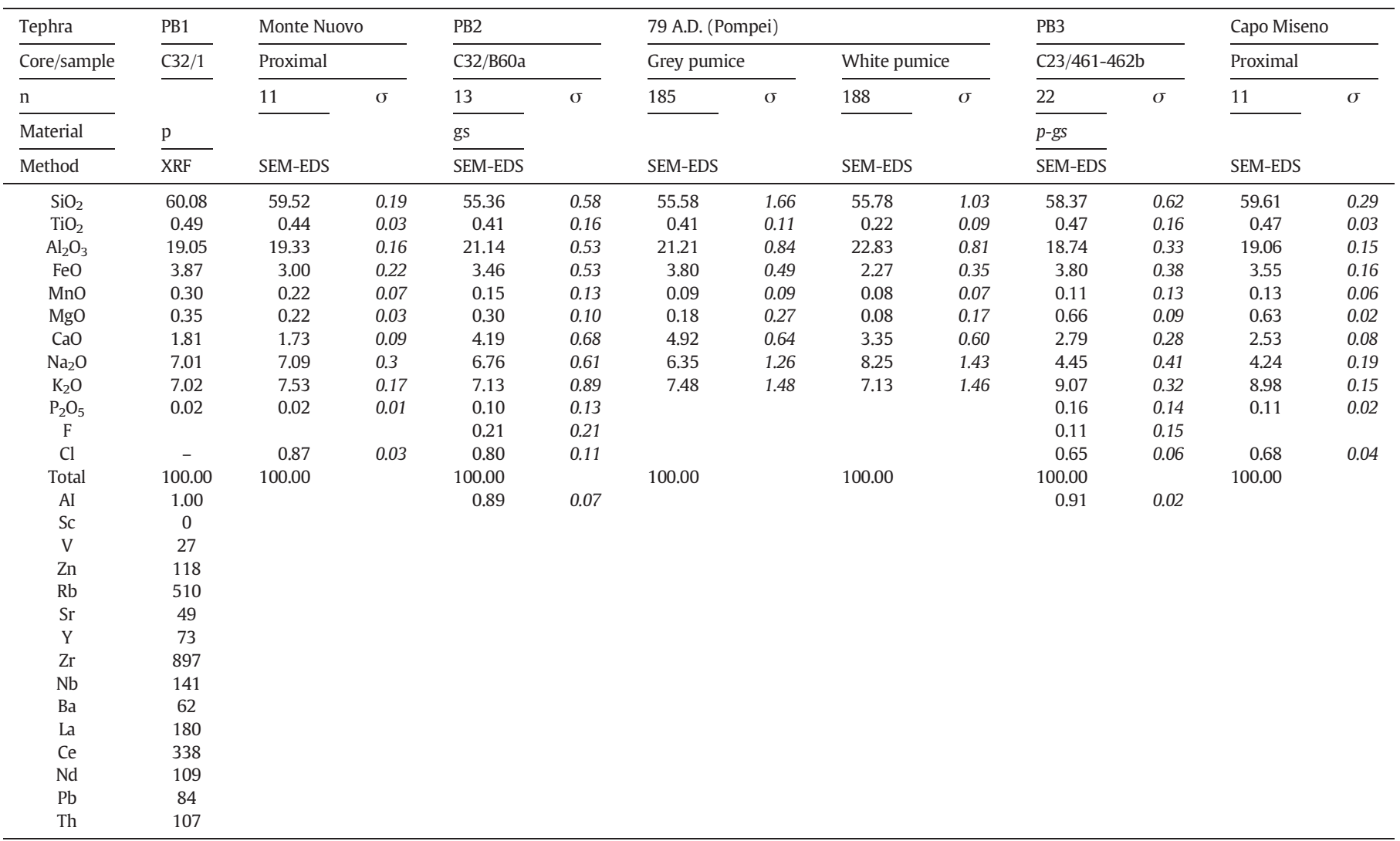

an average of $\sim 2$. $\mathrm{CaO}$ content is from $\sim 2 \%$ to $\sim 3 \%$ whereas $\mathrm{FeO}$ ranges from $\sim 3 \%$ to $\sim 4 \%$. This composition characterizes most of the products erupted at Campi Flegrei during the late Holocene. However, according to the lithofacies, stratigraphic position and the proximal character of the deposit (i.e. ash overlaid by pumice lapilli), we suggest a correlation of tefra PB3 with the products of Capo Miseno tuff cone. This monogenic vent has been dated with ${ }^{40} \mathrm{Ar} /{ }^{39} \mathrm{Ar}$ at $5090 \pm 140$ years BP by using incremental-heating procedure (Insinga et al., 2006) or alternatively at $3700 \pm 500$ years BP through laser heating procedure (Di Renzo et al., 2011).

\subsubsection{Age-depth model of the cored succession}

An age model for the cored sequence was constructed using absolute ages (years BP) derived from the correlation of tephras PB1, PB2 and PB3 with eruptive event documented in the literature (namely Monte Nuovo, Pompei, and Capo Miseno) (Fig. 9).

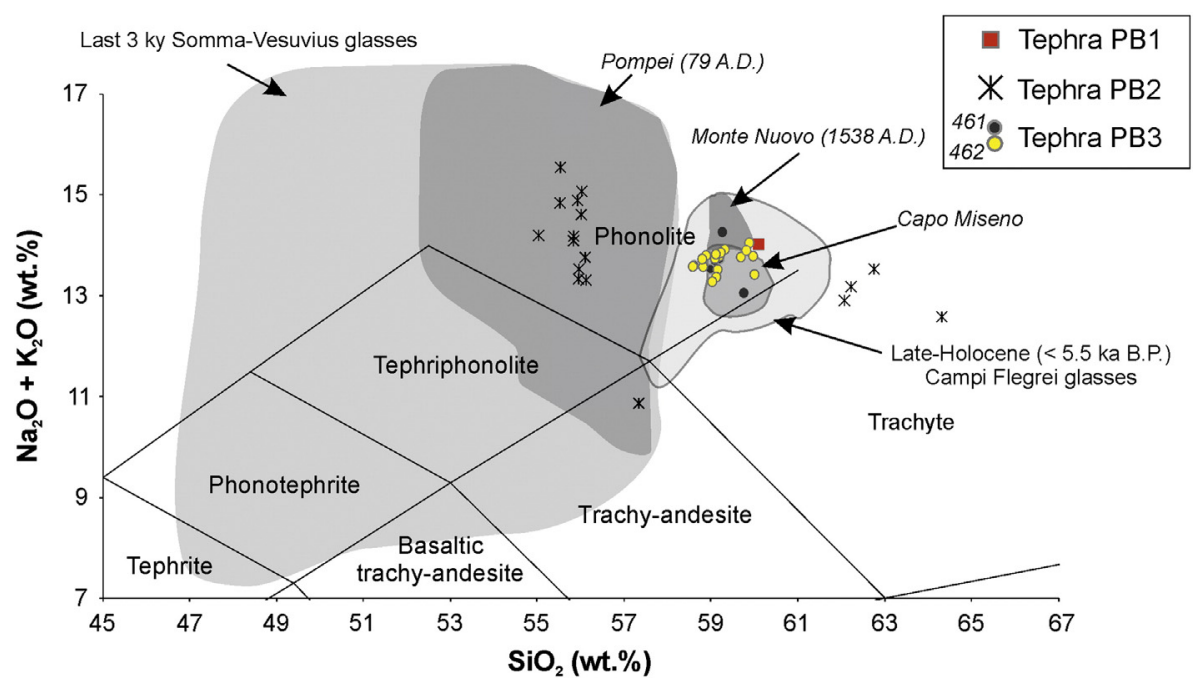

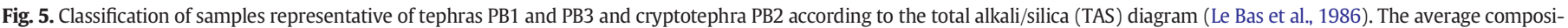

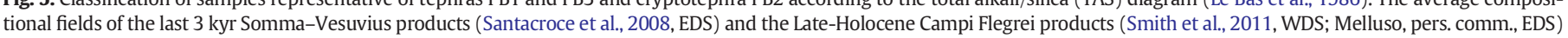
are reported for comparison. 


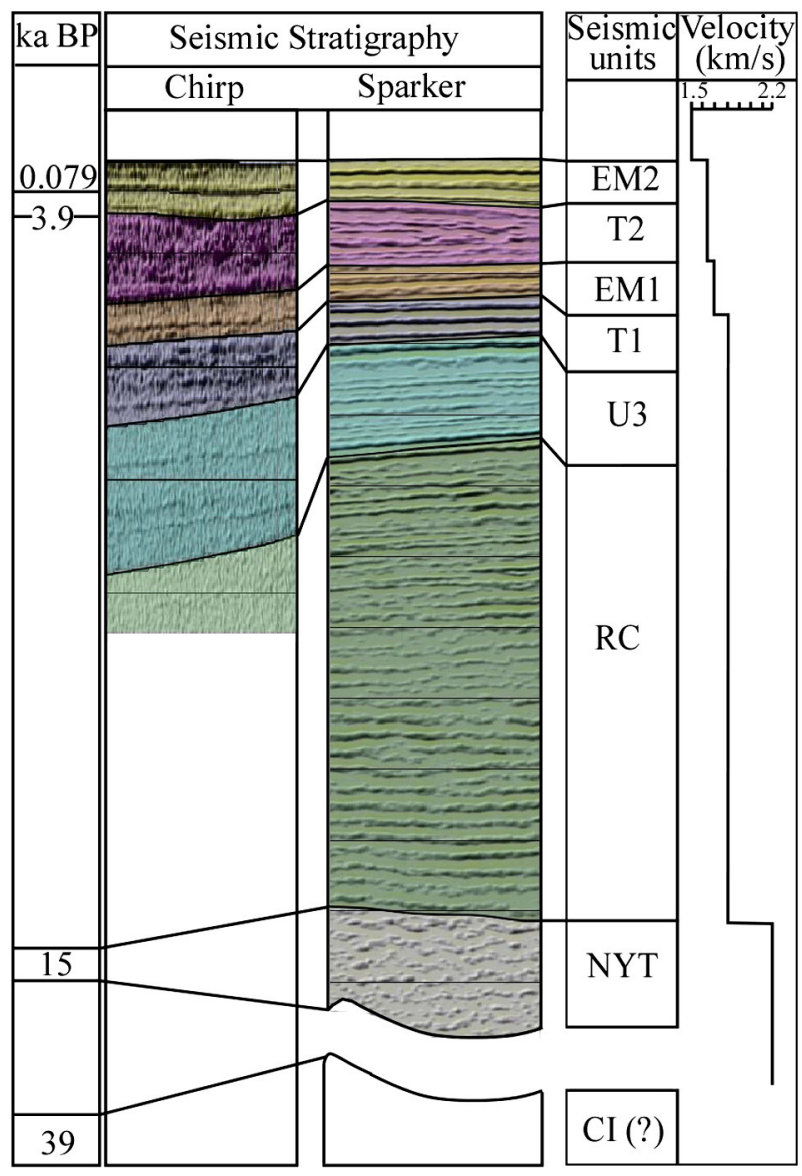

Fig. 6. Framework of seismic stratigraphic units recognized on Sparker and Sub-bottom Chirp profiles. Correlation between stratigraphic units and seismic velocities was based on analysis of seismic facies and lithostratigraphic data (Rosi and Sbrana, 1987; Di Vito et al., 1999).

The age-depth plot includes the radiocarbon calibrated age of $3904 \pm 60$ years BP we obtained from a mollusc shell sampled within the upper part of tephra PB3 (Capo Miseno). This datum is close to the age of $3700 \pm 500$ years BP reported for Capo Miseno eruption by Di Renzo et al. (2011).

\subsection{Seismic stratigraphic interpretation}

Seismic stratigraphic interpretation of the NYT caldera collapse structure and its sedimentary fill has been conducted on a series of depth-converted seismic sections that cross the Pozzuoli Bay along WNW-ESE and N-S directions.

Seismic profiles (Figs. 7 and 10-12) indicate that unit NYT represents the structural floor of the stratigraphic succession and is bounded at the top by a major unconformity (Figs. 6b and 7c). On the basis of its acoustic facies and stratigraphic position, this unit can be correlated to the Neapolitan Yellow Tuff deposits of the Campi Flegrei that are widely exposed along the cliffed coast of Posillipo (Sacchi et al., 2009 and references therein).

On section Msk_113, the top of NYT occurs at depths shallower than $\sim 150 \mathrm{~m}$ from the line termination up to shot 1000 (Fig. 7a). Between shots 1000 and 1500, the top of the unit abruptly changes in depth from $\sim 150 \mathrm{~m}$ to $\sim 200 \mathrm{~m}$, across a $\sim 2 \mathrm{~km}$ wide normal fault zone (Fig. 7c). The fault system can be traced on all seismic profiles throughout the area (Figs. 7 and 10-12). This structure accommodates a generalized downthrow of the inner caldera region corresponding to the central part of the Pozzuoli Bay. The projection of the fault zone in plan view defines a curvilinear pattern from the western part of the bay (Punta Pennata-Capo Miseno) to its eastern side (BagnoliFuorigrotta) and can be interpreted as the ring fault system (RFS) associated with the development of the NYT caldera collapse (Fig. 13) (e.g. Lipman, 2000 and references therein).

Moving in the NNE direction from the periphery of the bay towards its central-northern part, the top of NYT gently decreases from $200 \mathrm{~m}$ to $\sim 100 \mathrm{~m}$ b.s.l. This area is characterized by the occurrence of a broad ( $\sim \mathrm{km}$ wide) antiformal structure (Figs. 7 and 10-12) where the top of unit NYT cannot be continuously traced due to the sea floor multiples that obscure primary reflections.

Unit RC represents the first marine deposits unconformably overlying the NYT (Figs. 7 and 10-12) and it can be subdivided into two subunits (RC.1 and RC.2) (Fig. 7b). The unit fills up most of the caldera collapse structure. It reaches a maximum thicknesses of $80-90 \mathrm{~m}$ in the median sector of the bay (Fig. 11a) and is practically absent in the distal sectors of the bay outside the ring fault zone (Figs. 7, and 11-12).

Unit RC, particularly subunit RC1, is cross-cut by the ring fault zone and is locally characterized by obliteration of the seismic signal, associated with the occurrence of pore fluids at depth. The lowermost strata of subunit RC.2 are also offset by normal faulting, along with the NYT unit. Accordingly we infer that seismic units RC.1 and RC.2 have formed during and immediately after the major faulting that accompanied the caldera collapse. A shallow magmatic intrusion $\sim 300 \mathrm{~m}$ long and $26 \mathrm{~m}$ thick is observed along the ring fault zone, in the eastern part of the bay, at about the NYT-RC1 interface (Fig. 10, shots 430 and 600).

Well-stratified deposits of unit U3 conformably overlie unit RC throughout the bay (Figs. 7 and 10-12). The unit locally displays a divergent pattern of internal reflections (Figs. 10-11). It reaches the maximum thickness of $\sim 30 \mathrm{~m}$ close to the outer limit of the ring fault zone (Figs. 7 and 12a), while it pinches out, down to less than $9 \mathrm{~m}$, towards the top of the antiformal structure (Figs. 7, and 10-11). Lowamplitude reflectors locally occur within unit U3 above normal faults, suggesting the presence of trapped fluids that ascend through the fault zone (Fig. 7a and c). The geometry and internal pattern of reflections suggest that deposition of U3 was coeval with flank deformation and uplift of the antiformal structure recognized in the central-northern part of the Pozzuoli Bay.

The uppermost part of the sequence is represented by units T1, EM1, T2 and EM2 (Fig. 6-7 and 10-12). Units T1 and T2 reach their maximum thickness ( $7 \mathrm{~m}$ and $16 \mathrm{~m}$, respectively) at the periphery of the bay and pinch-out towards the flanks of the antiformal structure. Unit T1 is missing in the eastern sector of the bay. On the basis of their external and internal geometries, both units T1 and T2 have been interpreted as formed by gravity flow deposits (Fig. 7a and d).

Units EM1 and EM2 are conversely characterized by parallel internal reflections and remarkably constant thickness. Landwards, reflection terminations are truncated by a sharp erosional surface (Fig. 12e). The external geometry and the internal configuration of reflectors suggest that these units mostly represent inner shelf epiclastic deposits. In the distal part of the Pozzuoli Bay, unit EM2 was cored down to its base, which is represented by tephra PB3 (Capo Miseno) and dated at 3.9 ka BP

Towards the inner shelf, Unit EM2 may be subdivided into two subunits, namely EM2.C and EM2.H (Fig. 7e). Subunit EM2.C corresponds to a $\sim 270 \mathrm{~m}$ long prograding wedge that developed on the inner shelf slope (Fig. 7c). EM2-H (Fig. 7d) develops landwards of the inner shelf break (ICSB) and exhibits a low-angle prograding, wedge-shaped geometry. The base of this subunit correlates with tephra PB2 (Pompei eruption, Vesuvius) and can be consequently dated at 79 A.D. The remarkable backstepping of the prograding sequence suggests that subunit EM2-H was likely associated with a higher base level with respect to subunit EM2.C

In the apical sector of the antiformal structure detected in the centralnorthern part of the Pozzuoli Bay (profile Msk_112), the stratigraphic 

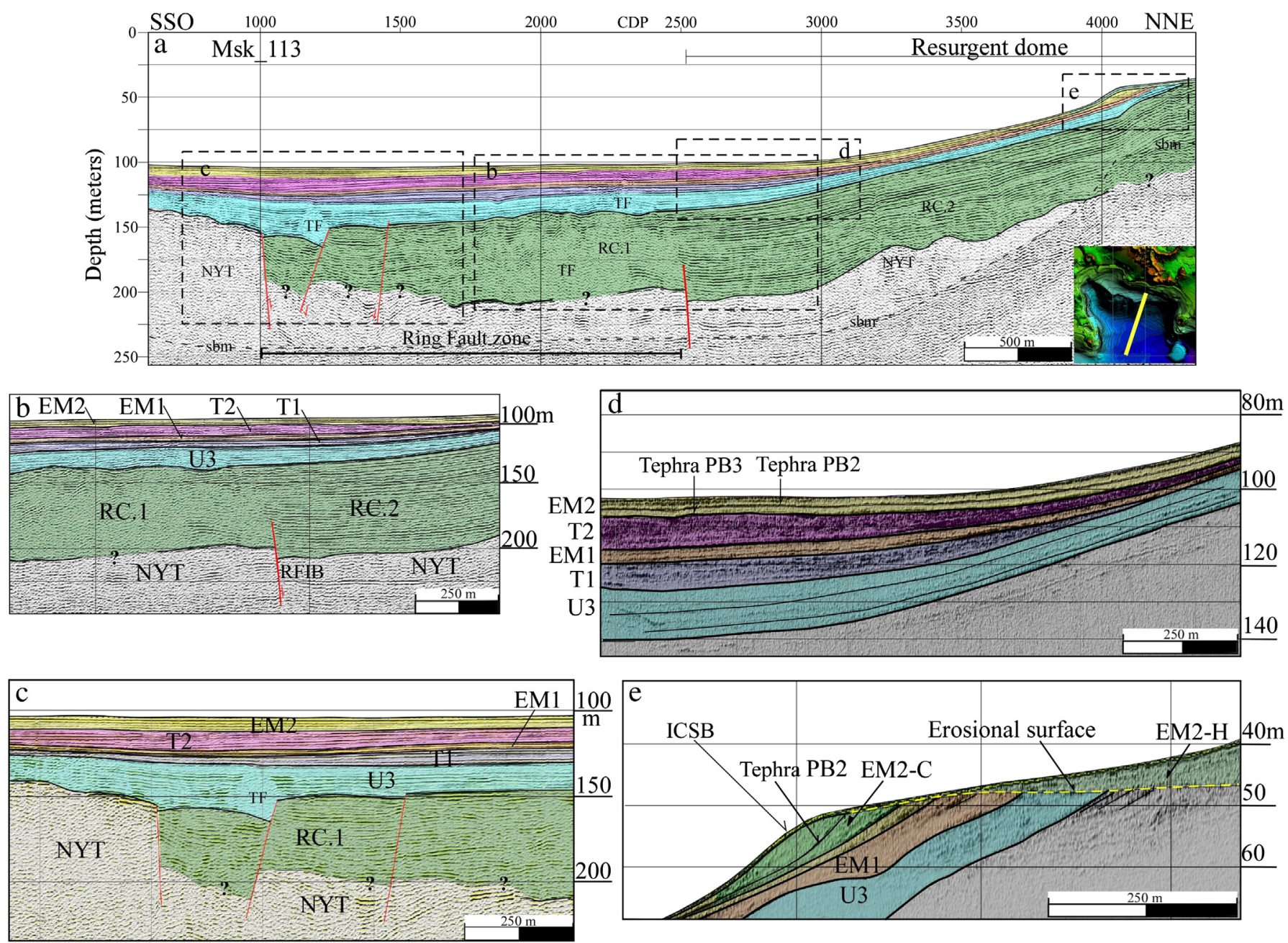

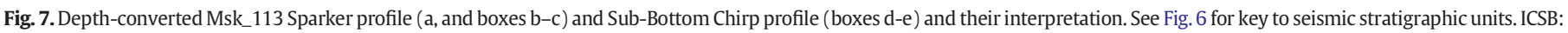
inner continental shelf break; Sbm.: sea bottom multiple; TF: trapped fluids.

sequence is affected by a series of high-angle normal faults, dipping $\sim 60^{\circ}-70^{\circ}$ that form a small "graben-like" structure. Faults generally have offsets up to $\sim 10 \mathrm{~m}$ and most of them deform the seafloor (Fig. 10, shots 1300-2050).

\section{Discussion}

During the last decades it has become clear that the understanding of geodynamic processes occurring at collapse calderas require effective integration of various methodological approaches and datasets (Martí et al., 2008).

Geophysical sounding has proven to provide invaluable insights into the interior of calderas and thus represents an important contribution to the understanding of subsurface dynamics. One limitation of conventional geophysical imaging (e.g. seismic tomography) of the shallow structure of buried calderas, however, may derive from limitation in spatial resolution of geophysical images, which inherently depends on the spacing between deployed instruments as well as on the inversion models.

The shallow marine setting of the NYT caldera in the Pozzuoli Bay represents a unique opportunity to obtain a high-resolution imaging of sub-seafloor stratigraphy and structures. In particular, the integration of the marine geophysical data with morpho-structural analysis and the geological calibration of the seismic record may provide a new perspective in the study of ring fault systems and resurgent structures associated with restless calderas on active continental margins, such as Rabaul (e,g, Saunders, 2001) and Satsuma Iwo-Jima (e,g, Ukawa et al., 2006).

\subsection{The caldera collapse structure and ring fault system}

Seismic interpretation showed that the NYT caldera collapse structure displays an ellipsoidal shape in plan view, with axes of $\sim 8 \mathrm{~km}$ and $\sim 7 \mathrm{~km}$, elongated in WNW-ESE direction (Fig. 13). The structural boundary of the caldera can be traced for a total length of $\sim 6 \mathrm{~km}$ from the western to the eastern sector of the Pozzuoli Bay and is represented by a complex ring fault zone that encircles the collapsed structure (Figs. 7 and 10-12). The width of the fault zone varies from 1 to $2 \mathrm{~km}$. The fault system is represented by a major series of inward-dipping faults (e.g. Figs. 10-12) and subordinate outward-dipping (antithetic) faults (e.g. Fig. 7c).

The ring fault zone produces a generalized downthrow of the NTY caldera floor that may locally exceed $80 \mathrm{~m}$. In the western sector of the Pozzuoli Bay, the ring fault system is characterized by the diffuse occurrence of pore fluids that likely ascend through the fault zone and locally permeate unit RC.1 and the lower part of unit U3 (e.g. Figs. 7 and 11). Evidence of active fluids vents over discrete seafloor sectors of the bay has been recently documented by Carmisciano et al. (2013).

The interpretation of the relative age of faults activity along the ring fracture system suggests a rejuvenation trend of faulting from the inner part towards the outer part of the ring fault zone (Figs. 7 and 10-12). 


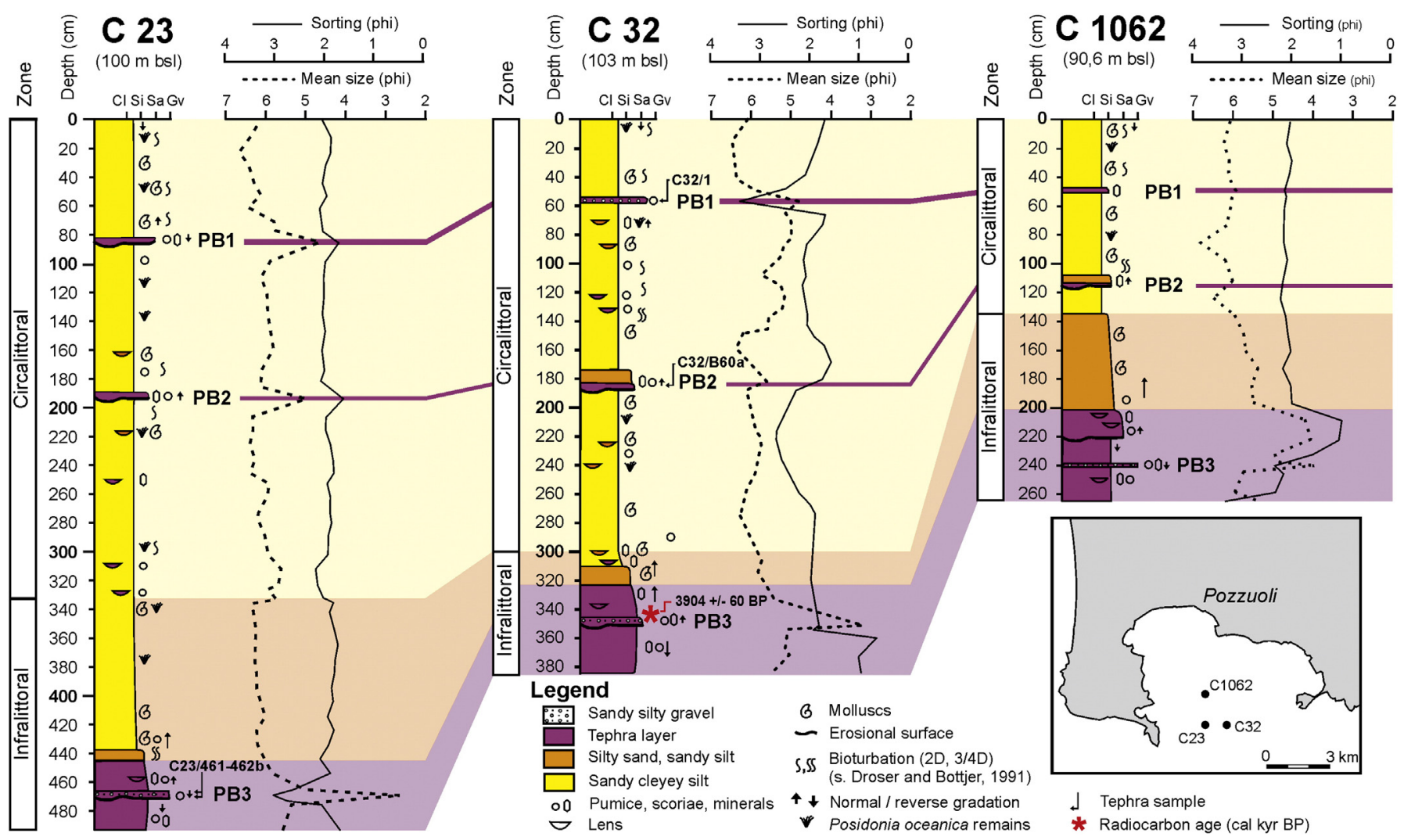

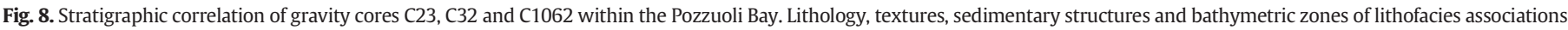
are indicated. Sorting and grain mean size are plotted against depth. Tephra layers PB1 and PB3 and cryptotephra PB2 have been correlated throughout the cored sections.

We infer that this trend may reflect the tendency of the initial inner caldera collapsed area (i.e. at $15 \mathrm{ka}$. BP) to increase its width through time.

Seismic interpretation of profile Msk_112 has illustrated the occurrence of a magmatic intrusion along the ring fault zone, offshore Bagnoli, in the eastern part of the Pozzuoli Bay (Fig. 10). The magmatic body has the shape of a small laccolith that intrudes the lower part of unit RC and deforms the above strata, up to the base of unit EM2 (3.9 ka BP). The inferred age of this intrusion is likely coeval with similar structures (e.g. M. Olibano lava dome) already described onland (Fig. 13) (e.g. Isaia et al., 2009; Melluso et al., 2012).

The reconstructed pattern of the ring fault zone in the Pozzuoli Bay shows a good correlation with the structural border of the NYT caldera inferred by previous studies from other geophysical data, including low-resolution active seismic tomography images (Dello Iacono et al., 2009) and the pattern of horizontal derivative of gravity anomalies (Florio et al., 1999).

\subsection{The caldera resurgence}

A striking feature of the central-northern part of the Pozzuoli Bay is represented by the antiformal structure recognized on seismic profiles that is also evident in the morpho-bathymetry of the seafloor (Figs. 2-3, 7 and 10-11). The structure is surrounded by the inner boundary of the ring fault system and can be interpreted as the resurgent dome of the NYT caldera. The resurgence is associated with significant deformation and uplift of the inner caldera region, as indicated by the growth of strata of unit U3 offshore, and by the marine deposits nowadays exposed onshore with an elevation of $\sim 30 \mathrm{~m}$ a.s.l., at La Starza (Cinque et al., 1985; Rosi and Sbrana, 1987; Di Vito et al., 1999; Orsi et al., 1999).
On the basis of our interpretation, we estimate that a maximum cumulative uplift of $\sim 180 \mathrm{~m}$ has been reached at the top of the resurgent dome, over a distance of $\sim 4,5 \mathrm{~km}$ from the base of the structure. As a consequence, we infer that the 60-80 $\mathrm{m}$ uplift of the caldera resurgence documented at La Starza onland (Cinque et al., 1985; Amore et al., 1988) represents less than the half of the uplift history of the entire structure in the last $15 \mathrm{ky}$.

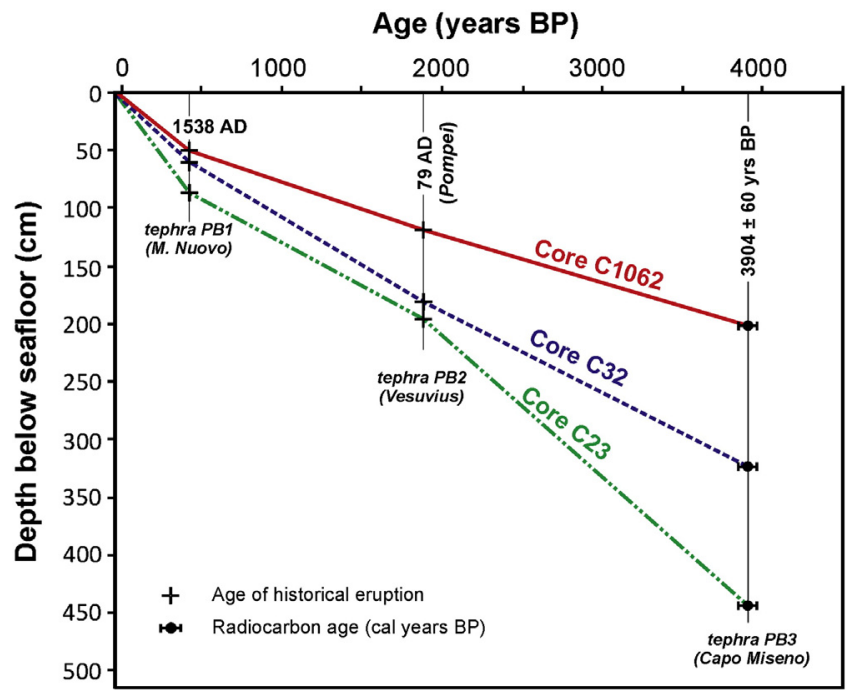

Fig. 9. Age-depth plot of gravity cores C23, C32 and C1062 based on the interpreted ages of the tephra layers PB1 and PB3 and cryptotephra PB2 (see also Table 1). 


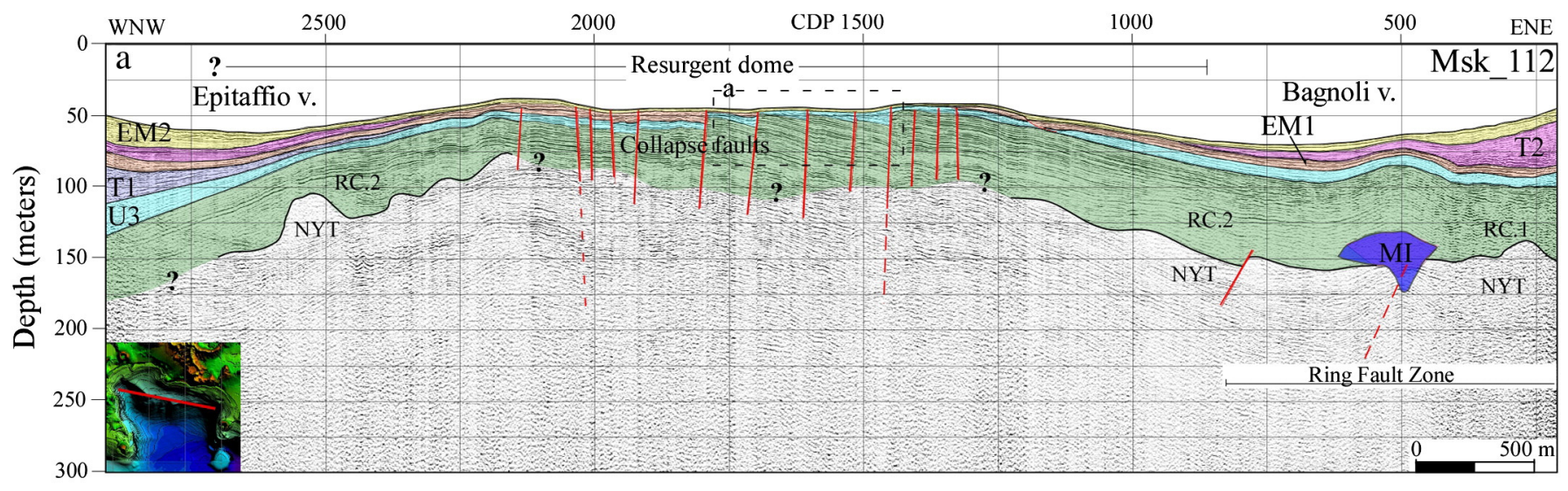

T1 T2 Gravity flow deposits

U3 Syn resurgence dome uplift deposits

RC.1 Sedimentary cover that overly the NYT above the RFZ

RC.2 Sedimentary cover that overly the NYT from the RFIB landward

EM1 EM2 Epiclastic deposits

MI Magmatic intrusion

NYT Neapolitan Yellow Tuff

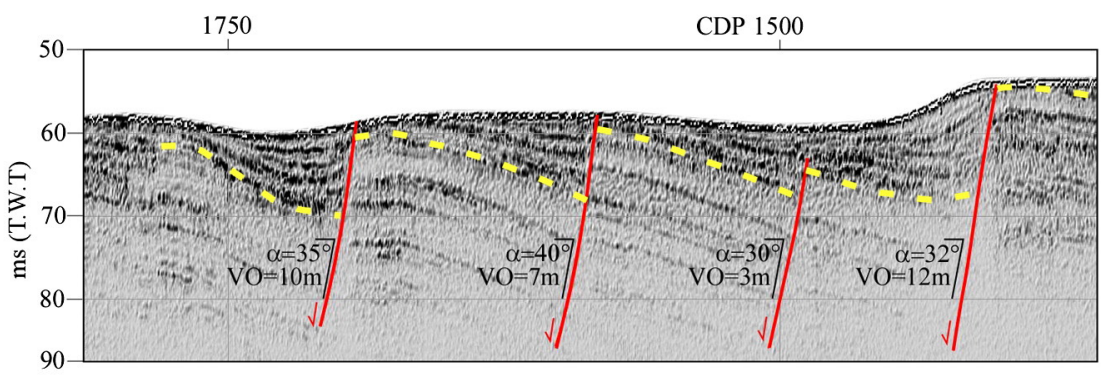

Inferred fault

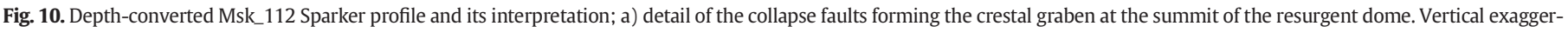
ation is 1:6.

Offshore, the resurgent dome displays limited internal brittle deformation, with the notable exception of its central summit area where a set of normal faults forms a small graben-like structure (Figs. 11 and 13). According to classic models of resurgent calderas (e.g. Komuro et al., 1984 Lipman, 1997; Cole et al., 2005), this structure, often referred to as "apical graben" can be explained as the consequence of extension of the resurgent structure in the area of maximum convex curvature.

Multibeam bathymetry coupled with seismic data has shown that the median sector of the Pozzuoli Bay is characterized by a morphostructural depression surrounding the resurgent dome and approximately corresponding to the thalweg of the Epitaffio valley in the western sector of the Pozzuoli Bay and the Bagnoli valley to the east (Fig. 3). According to the conventional terminology of piston collapse calderas, these depressions may be described as segments of the caldera collar (e.g. Lipman, 1997, Cole et al., 2005).

An interesting feature revealed by seismic interpretation is the Punta Pennata structure (see also Milia and Torrente, 2000; Milia et al., 2003), a minor antiformal lineament that deforms the seafloor along the southwestern border of the caldera (Fig. 11). Our data suggest that the Punta Pennata structure may be regarded as the result of a broad bending of strata that accommodate local compression within the fault zone between the base of resurgent structure and the footwall of the ring fault system (e.g. Borgia et al., 2000).

\subsection{Uplift of La Starza marine terrace and post-Roman subsidence}

Previous studies have documented that the marine stratigraphic succession cropping out along the coastal cliff of La Starza (10.5$4.0 \mathrm{ka} \mathrm{PB}$ ) has been brought to subaerial exposure as a consequence of $\sim 30 \mathrm{~m}$ uplift that occurred during a $\sim 200$ years period of unrest between 4.1 and $\sim 3.9 \mathrm{ka} \mathrm{BP}$ (Isaia et al., 2009), with an average uplift rate in the order of $150 \mathrm{~mm}$ /year (Fig. 14). As the oldest marine layers of La Starza succession were deposited at a water depth of 30-50 m b.s.l. (Amore et al., 1988), it can be concluded that total net uplift documented at La Starza is in the order in $60-80 \mathrm{~m}$, over a period of $\sim 6.5 \mathrm{ka}$, with an average uplift rate of 9-12 $\mathrm{mm} / \mathrm{year}$.

The interpretation of seismic profiles also suggest that the maximum uplift measured over the entire resurgent structure, from the top of the NYT caldera resurgence to its base offshore, was in the order of $\sim 180 \mathrm{~m}$, with an average uplift rate in the order of $12 \mathrm{~mm} /$ year, over the last $15 \mathrm{ky}$. We also infer that a significant part of the early uplift history of the NYT caldera resurgence (15.0-10.5 ka BP) occurred in underwater marine setting and was practically coeval with the eustatic sea-level rise following the last glacial maximum.

Submerged archaeological remains of Roman age, i.e. buildings, roads and port facilities, originally built at, or slightly above the sea level along the western coast of the Pozzuoli Bay (Dvorak and Mastrolorenzo, 1991; Orsi et al., 1996; Passaro et al., 2012), provide indication that the long term uplift of the caldera resurgence was interrupted at $20 \mathrm{ka}$ BP and the coastal area between Pozzuoli and Capo Miseno underwent $\sim 10 \mathrm{~m}$ of subsidence during post-Roman times (Fig. 14).

Our data showed that the present-day water depth of the morphologic break that marks the edge of the prograding unit EM2-C (ICSB in Figs. 2-3, 7, 16) varies from $25 \mathrm{~m}$ b.s.l. in the north western part of the Pozzuoli Bay (offshore Baia) to $\sim 45 \mathrm{~m}$ b.s.l. in the south eastern part (offshore Bagnoli). This indicates a remarkable tilting of the inner caldera resurgence towards ESE during the post-Roman subsidence phase.

The accommodation space created during the last $\sim 2$ kyr resulted in a significant backstepping of the present-day coastal prograding wedge 

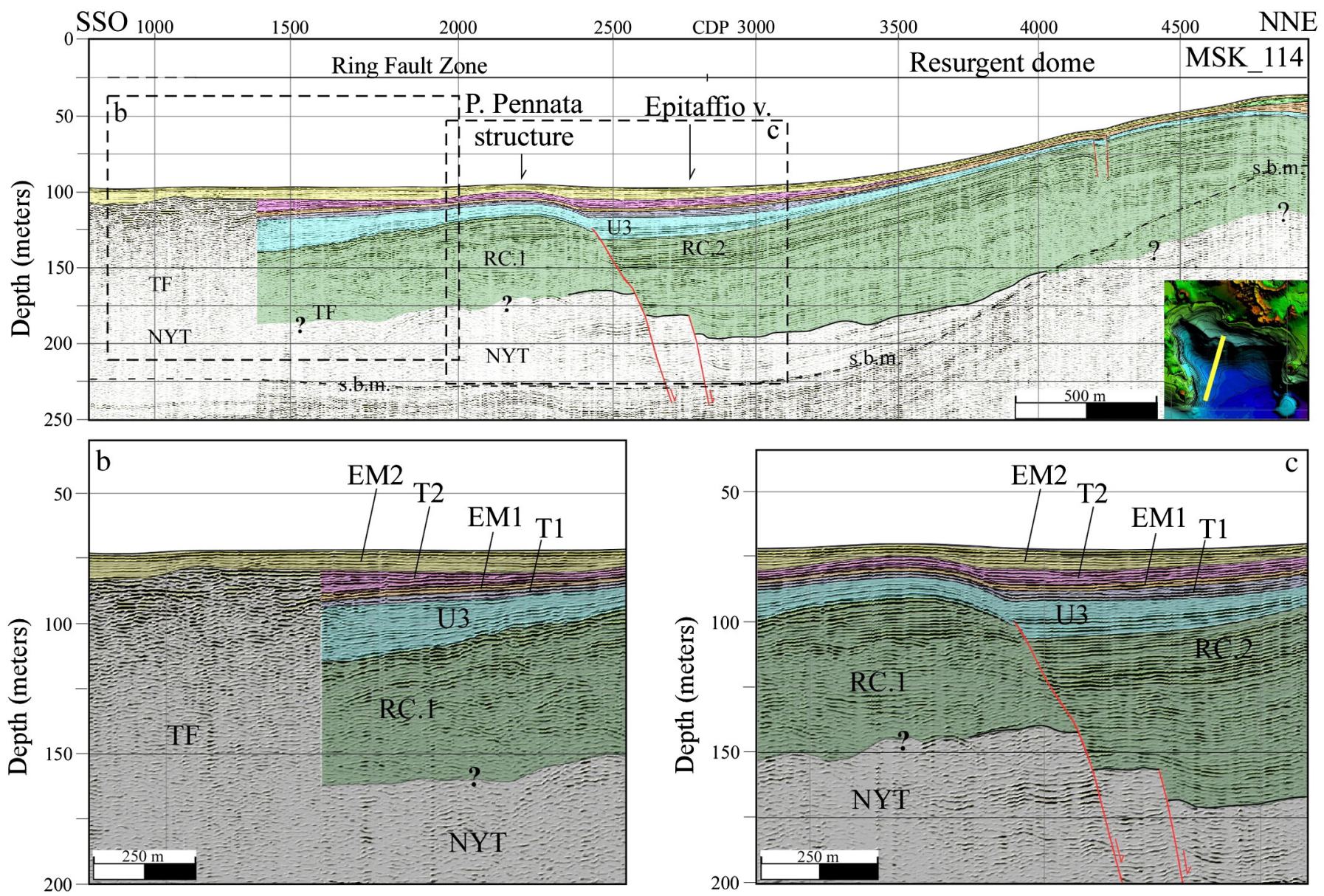

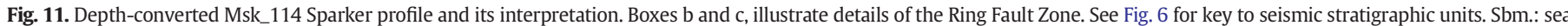
bottom multiple; TF: trapped fluids. Vertical exaggeration is 1:6.

(unit EM2-H, in Fig. 7e) and was accompanied seaward by the deposition of a deepening-upward sequence, with transition from infralittoral to circalittoral environment (Fig. 8).

\subsection{Kinematic reconstruction of the NYT caldera during the last $15 \mathrm{ky}$}

To provide a semi-quantitative kinematic analysis of vertical movements (uplift/subsidence) following the NYT eruption, we have restored the NNE-trending, depth-converted Msk_113 profile (Fig. 7a). The evolution is summarized in four stages ( $A$ to $D$, from older to younger) namely corresponding to; a) age of the top of unit RC; b) age of the top of unit U3; c) $2.0 \mathrm{ka} \mathrm{BP}$ and d) present day (Figs. 15 and 16).

Absolute ages for the top of RC and U3 units are unknown. An estimate of the age for the top of U3 was attempted by extrapolating the age-depth curve derived for core C32 (Figs. 9 and 14) to the underlying unit EM1. Also, we have assumed that the time interval for the deposition

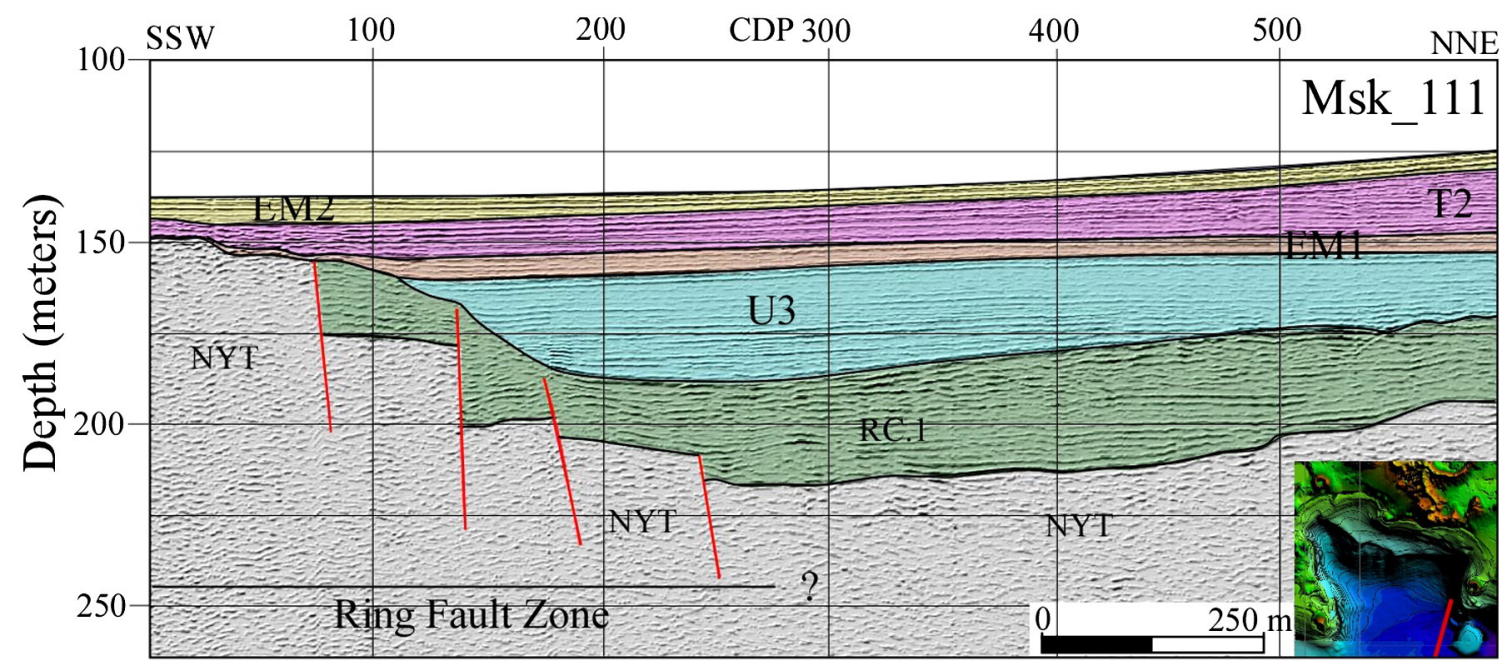

Fig. 12. Depth-converted Msk_111 Sparker profile and its interpretation. See Fig. 6 for key to seismic stratigraphic units. Vertical exaggeration is $1: 6$. 


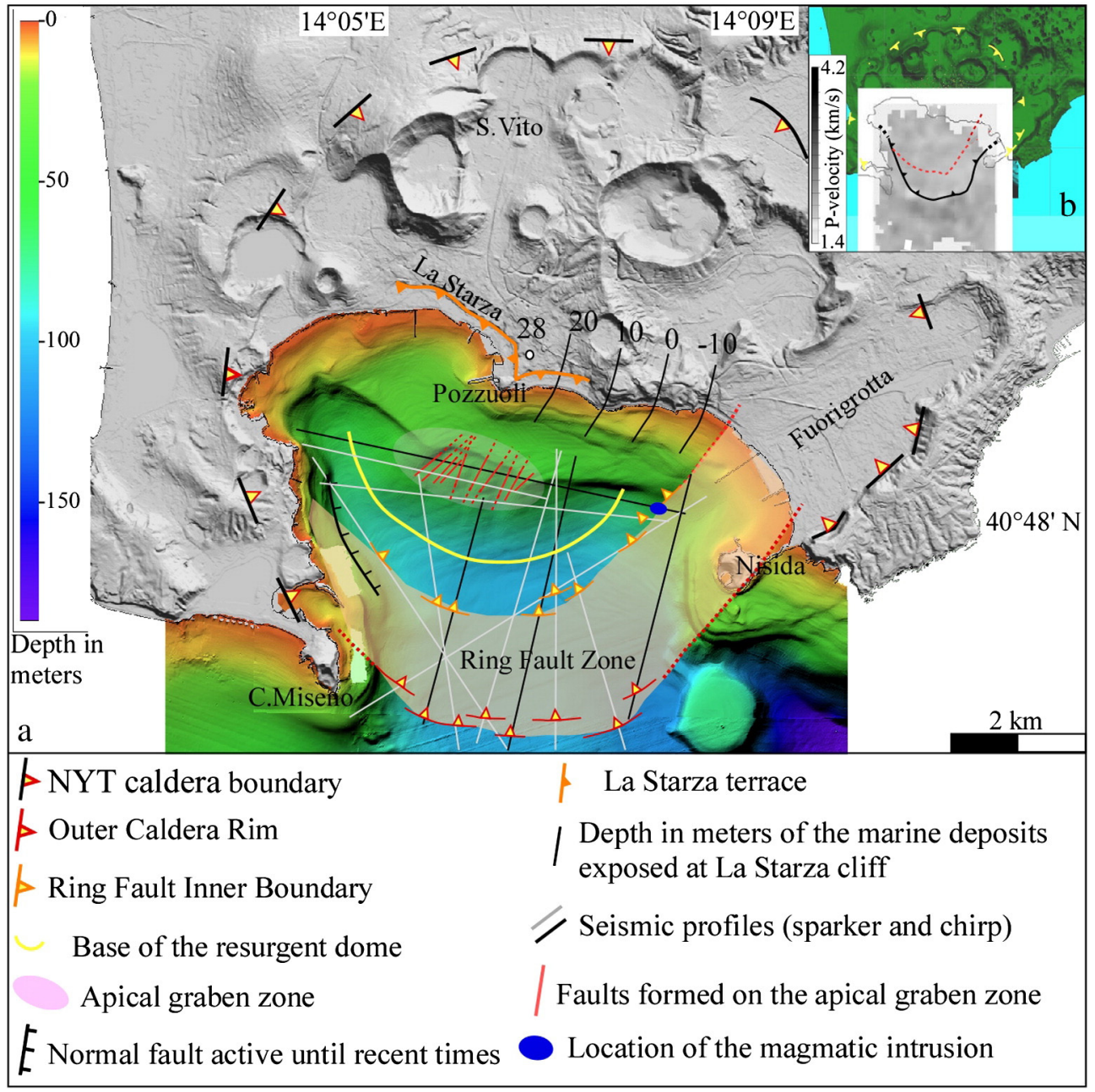

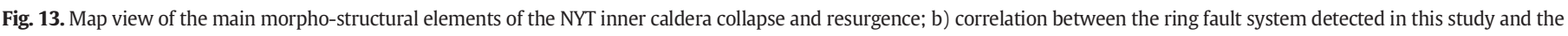
northern limit of the arc shape P-velocity anomaly, between depths of 0.25 and $0.5 \mathrm{~km}$ documented by Dello lacono et al.(2009).

of units $\mathrm{T} 1$ and $\mathrm{T} 2$ is negligible as these units are the result of gravity flow processes that commonly produce relatively thick deposits in a relatively short time. Consequently, we have considered the age for the top of unit U3 as corresponding to the estimated age of the lower boundary of unit EM1, ( 6.6 kyr) (Fig. 15).

In order to construct the restored sections we have: a) removed sediments younger than the reference time slice; b) included paleobathymetry derived by unit EM2.C and the reconstructed the eustatic sea-level curve for the Napoli Bay since the last glacial maximum (Lambeck et al., 2011); c) added the (uncompacted) thickness of the stratigraphic sequence at depth starting from the paleobathymetric datum.

\subsubsection{Stage A (15.0 ka BP)}

The NYT eruption was followed by a caldera collapse along the ring fault system (Fig. 16a). The collapsed structure hosted $\sim 60 \mathrm{~m}$ of volcaniclastic and epiclastic sediments (unit RC) that accumulated at high depositional rates during a relatively short time period. Sea level was approximately $93 \mathrm{~m}$ lower than the present-day level (Lambeck et al., 2011). The lack of deposits coeval with unit RC outside the caldera suggests that palaeo water depth was less than $20 \mathrm{~m}$ in the periphery of the collapsed area. Consequently we infer that the initial palaeo water depth inside the caldera collapse was in the order of 60-80 m.

\subsubsection{Stage B (15.0-6.6 ka BP)}

An inner caldera resurgent dome started to form in the northern sector of the future Pozzuoli Bay (Fig. 16b). At the end of this stage, the top of the NYT was uplifted from $200 \mathrm{~m}$ b.s.l. in the southern part of the bay up to $\sim 100 \mathrm{~m}$ b.s.l. towards the summit of the resurgent dome. During this time interval, we may estimate an average net uplift rate of $\sim 12 \mathrm{~mm} /$ year for the offshore resurgent structure. This is practically the same uplift rate that can be derived by geomorphologic data reported in the literature for La Starza area (Cinque et al., 1985; Amore et al., 1988). At $\sim 6.6 \mathrm{ka}$ BP, the sea level reached $\sim 7 \mathrm{~m}$ below the present-day level thus creating accommodation space for the deposition of unit $\mathrm{U} 3$ above the flanks of the uplifting resurgent structure and outside the inner caldera region.

\subsubsection{Stage C (6.6-2.0 ka BP)}

This stage is characterized by the deposition of gravity flow units interbedded with circalittoral deposits in the deepest sector of the bay (Fig. 16c). An infralittoral prograding wedge (unit EM2-C) started to form towards the inner continental shelf of the Pozzuoli Bay, at a water depth of $\sim 20 \mathrm{~m}$ b.s.l. The varying thickness of the upper part of the sedimentary succession, suggests that vertical movements (uplift/ subsidence) with different magnitudes possibly occurred in the area during this time interval. 


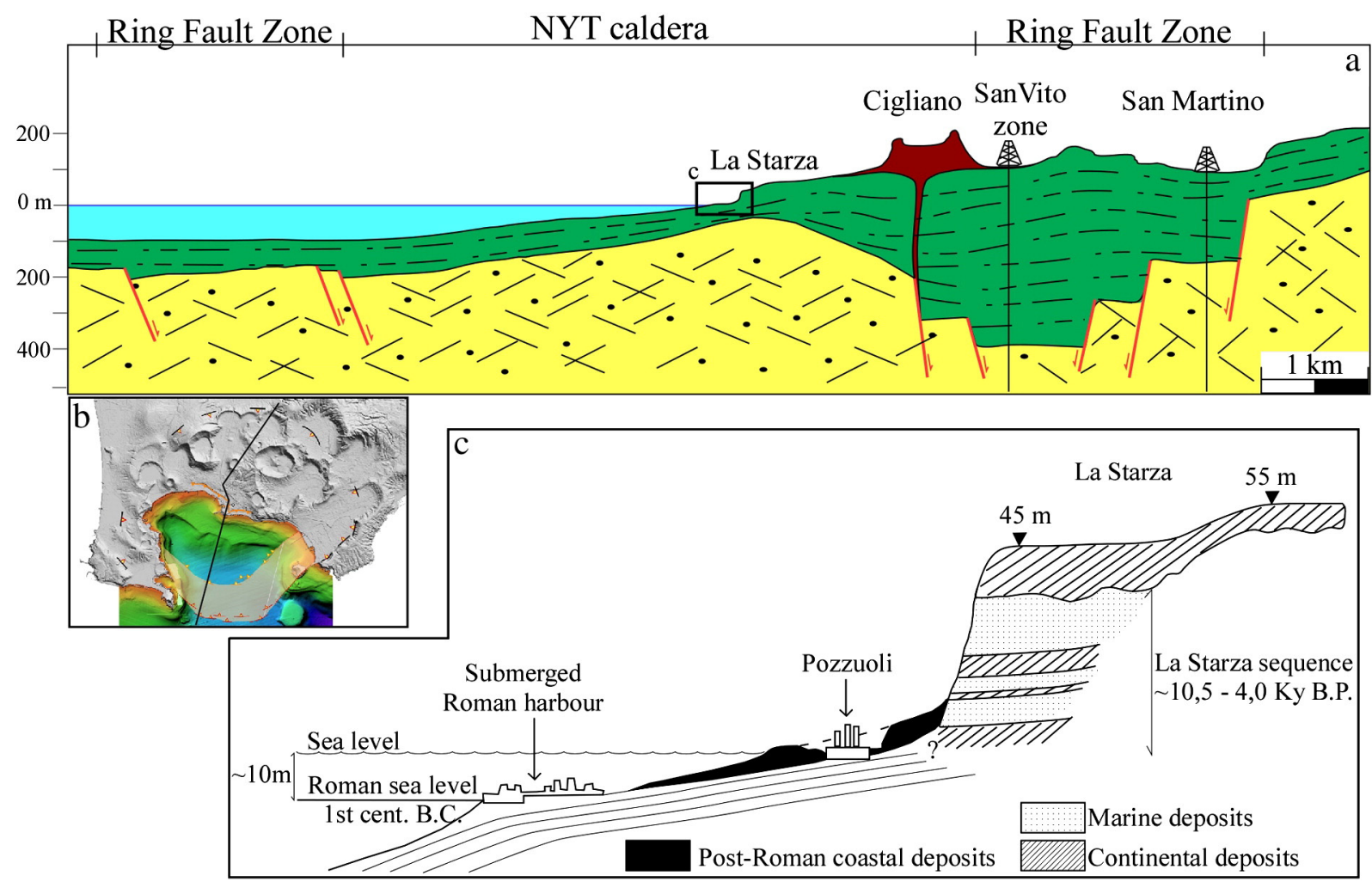

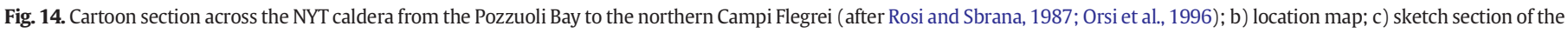
Pozzuoli coastal zone at La Starza (after Cinque et al., 1985).

\subsubsection{Stage D (2.0 ka BP-Present)}

At $\sim 2$ ka BP the sea level was $\sim 1 \mathrm{~m}$ lower than the present day. The infralittoral prograding wedge (unit EM2-C) that, still during Roman times, was forming at a water depth of $\sim 20 \mathrm{~m}$ b.s.l, in substantial equilibrium with the hydrodynamic regime (Pepe et al., 2013) has now subsided to $40 \mathrm{~m}$ b.s.l (Fig. 16d). The subsidence phase detected offshore is in agreement with documented archaeological evidences of ground subsidence between the Roman period and the Middle Ages in the area of Pozzuoli. The accommodation space created during the last $\sim 2$ kyr was partly filled with sediments of unit EM-H. Seaward, subsidence was documented by a deepening-upward sequence, with a transition from infralittoral to circalittoral conditions, throughout the cored succession.

\section{Conclusion}

The integrated analysis of geophysical and geological data acquired off the Campi Flegrei in the Pozzuoli Bay, has provided new insights into the shallow structure and evolution of the NYT collapse caldera over the last $15 \mathrm{kyr}$. The main results of this study can be summarized as follows:

1) The offshore collapse structure of the NYT caldera displays an ellipsoidal shape in plan view, with axes of $\sim 8 \mathrm{~km}$ and $\sim 7 \mathrm{~km}$, elongated in WNW-ESE direction. The thickness of the caldera fill is in the order of $60 \mathrm{~m}$ within the Pozzuoli Bay.

2) The inner caldera region is characterized by a resurgent dome, $5 \mathrm{~km}$ in diameter, bounded by a 1-2 km wide ring fault system. The style of deformation of the resurgent structure can be described in terms of a broad antiformal folding, accompanied by subordinate brittle deformation, mostly concentrated in a small apical graben at the summit of the resurgent dome. The average net uplift rate of the resurgent structure has been in the order of 9-12 mm/year between 10.5 ka PB and 4.0 ka PB.
3) The ring fault zone of the NYT caldera is represented by a system of inward-dipping normal faults and minor outward-dipping (antithetic) individual faults. The kinematics of faulting suggests a widening of the initial inner caldera collapse through time.

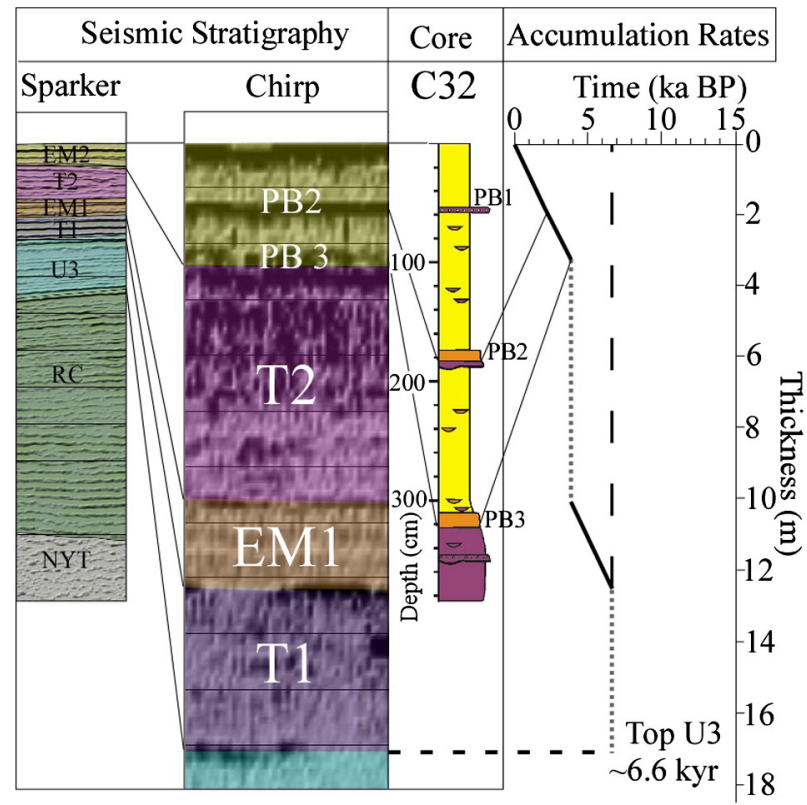

Fig. 15. Sediments accumulation rate plot for gravity core C32. Tephra PB1: Monte Nuovo eruption (1538 A.D.); cryptotephra PB2: Somma-Vesuvius eruption (Pompei, 79 A.D.); tephra PB3: Capo Miseno eruption (3.9 ka BP, this study). Inferred ages of seismic units $\mathrm{T} 1$ to EM2 are also reported (see text for discussion). 


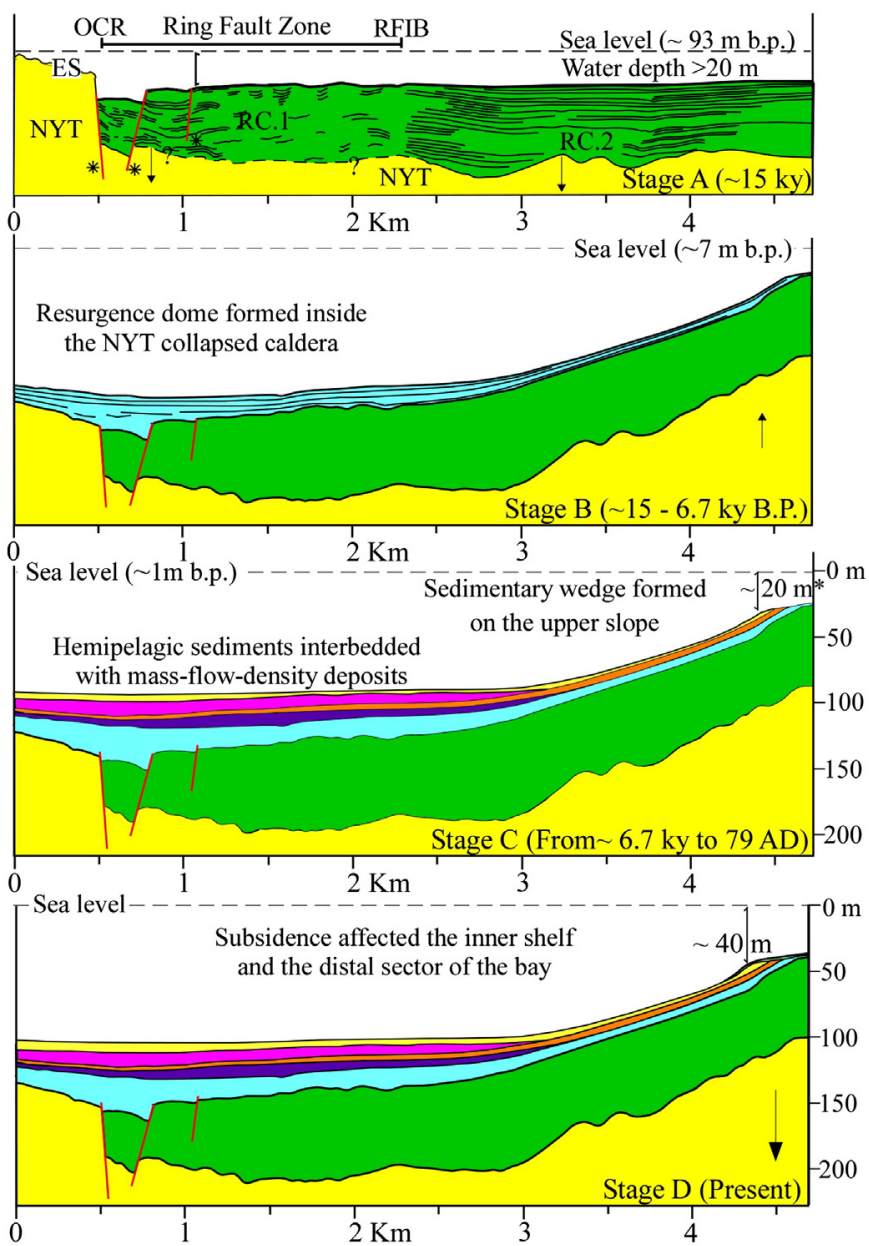

Fig. 16. Stages of evolution of the NYT caldera: a) 15.0 ka BP; b) 15.0-6.6 ka BP; c) 6.6-2.0 ka BP; d) 2.0 ka BP-Present. Asterisks indicate period of active faulting. Arrows indicate uplift/subsidence. Vertical exaggeration is $1: 8$.

4) In the western sector of the Pozzuoli Bay, the ring fault system is characterized by the diffuse occurrence of pore fluids that ascend at shallow depths through the fault zone and may locally result in active fluid vents at the seafloor.

5) A shallow magmatic intrusion has been detected along the ring fault zone, in the eastern part of the Pozzuoli Bay, offshore Bagnoli. The magmatic body has the shape of a small ( $300 \mathrm{~m}$ long and $26 \mathrm{~m}$ ) thick laccolith. The inferred age of the intrusion is $3.9 \mathrm{ka} \mathrm{BP}$.

6) Soon after the NYT eruption ( $15 \mathrm{kyr} B P)$, marine conditions prevailed over the collapsed caldera structure in the Pozzuoli Bay. Uplift rates of the resurgent structure were initially lower than the post glacial sea-level rise. The mid-Holocene decrease in the rate of sea-level rise marked the onset of the uplift to subaerial exposure of the Pozzuoli coastal sector at La Starza.

7) The present-day water depth of the infralittoral prograding wedge of the Pozzuoli Bay (25-45 m b.s.l.) indicates 5 to $25 \mathrm{~m}$ of post-Roman differential subsidence and tilting of the inner caldera resurgence towards ESE.

\section{Acknowledgments}

Gravity cores and swath bathymetry data used in this study were acquired by the IAMC-CNR, Naples, on board of the R/V URANIA during a series of oceanographic cruises between 1997 and 2004 for the geological mapping of the Italian coastal zone (CARG project). Sub-bottom Chirp and high-resolution single channel (sparker) reflection seismic data were mostly acquired by the IAMC-CNR, Naples on board of the
R/V URANIA in 2010 during Oceanographic cruise Marisk-10 in cooperation with the University of Palermo.

XRF and SEM-EDS data were acquired at the Centro Interdipartimentale di Servizi per Analisi Geomineralogiche (CISAG), University of Naples Federico II. The ${ }^{14} \mathrm{C}$ AMS analyses were conducted at the Centre for Isotopic Research for Cultural and Environmental Heritage (CIRCE) Laboratory of the Second University of Naples, Caserta.

Financial support for this research was provided by the Programma Operativo Nazionale (PON) funded by the Italian Ministry of University and Research-Project PON-MONICA (grant PON01_01525).

We are grateful to Silvio Rotolo and Luigi Ferranti for providing helpful comments during the preparation of the manuscript, Roberto dè Gennaro and Paola Petrosino for their skilful assistance during microprobe acquisition, and Patricia Sclafani for the revision of the English text. We also thank two anonymous reviewers who helped us to improve the early version of the manuscript.

\section{References}

Acocella, V., 2008. Structural development of calderas: a synthesis from analogue experiments. In: Gottsmann, J., Marti, J. (Eds.), Caldera Volcanism: Analysis, Modelling and Response. Developments in Volcanology, 10. Elsevier, pp. 285-311.

Acocella, V., 2010. Evaluating fracture patterns within a resurgent caldera: Campi Flegrei, Italy. Bulletin of Volcanology 72, 623-638.

Acocella, V., Cifelli, F., Funiciello, R., 2000. Analogue models of collapse calderas and resurgent domes. Journal of Volcanology and Geothermal Research 104, 81-96.

Acocella, V., Cifelli, F., Funiciello, R., 2001. The control of overburden thickness on resurgent domes: insights from analogue models. Journal of Volcanology and Geothermal Research 111, 137-153.

Acocella, V., Funiciello, R., Marotta, E., Orsi, G., de Vita, S., 2004. The role of extensional structures on experimental calderas and resurgence. Journal of Volcanology and Geothermal Research 129, 199-217.

Amore, O.F., Bonardi, G., Ciampo, G., De Capoa, P., Perrone, V., Sgrosso, I., 1988. Relazioni tra "Flysch Interni" e domini appenninici: reinterpretazione delle formazioni di Pollica, S. Mauro e Albidona e il problema dell'evoluzione inframiocenica delle zone esterne Appenniniche. Memorie della Società Geologica Italiana 41, 285-297.

Barberi, F., Cassano, E., La Torre, P., Sbrana, A., 1991. Structural evolution of Campi Flegrei Caldera in light of volcanological and geophysical data. Journal of Volcanology and Geothermal Research 48 (1-2), 33-49.

Battaglia, M., Troise, C., Obrizzo, F., Pingue, F., De Natale, G., 2006. Evidence for fluid migration as the source of deformation at Campi Flegrei caldera (Italy). Geophysical Research Letters 33, L01307.

Bellucci, F., Milia, A., Rolandi, G., Torrente, M.M., 2006. Structural control on the Upper Pleistocene ignimbrite eruptions in the Neapolitan area (Italy): planar volcano tectonic faults versus caldera faults. In: De Vivo, B. (Ed.), Vesuvius and volcanism of the Campanian Plain. Developments in Volcanology, 9. Elsevier, Amsterdam, pp. $163-180$.

Berrino, G., Corrado, G., Luongo, G., Toro, B., 1984. Ground deformation and gravity change accompanying the 1982 Pozzuoli uplift. Bulletin of Volcanology 47 (2), 187-200.

Borgia, A., Lanari, R., Sansosti, E., Tesauro, M., Berardino, P., Fornaro, G., Neri, M., Murray, J.B., 2000. Actively growing anticlines beneath Catania from the distal motion of Mount Etna's decollement measured by SAR interferometry and GPS. Geophysical Research Letters 27 (20), 3409-3412.

Branney, M.J., Kokelaar, B.P., 1994. Volcanotectonic faulting, softstate deformation and rheomorphism of tuffs during development of a piecemeal caldera, English Lake District. Geological Society of America Bulletin 106, 507-530.

Bronk Ramsey, C., 2009. Bayesian analysis of radiocarbon dates. Radiocarbon 51, 337-360.

Bruno, P.P., 2004. Structure and evolution of the Bay of Pozzuoli (Italy) by marine seismic data. Bulletin of Volcanology 66, 342-355.

Budillon, F., Conforti, A., Tonielli, R., D'Argenio, B., Marsella, E., 2011. Morfobatimetria del Golfo di Pozzuoli. In: Lirer, L. (Ed.), I Campi Flegrei, storia di un campo vulcanico. Quaderni dell'Accademia Pontaniana, Napoli, pp. 105-120.

Burov, E.B., Guillou-Frottier, L., 1999. Thermomechanical behavior of large ash flow calderas. Journal of Geophysical Research 104 (B10), 23081-23109.

Capuano, P., Achauer, U., 2003. Gravity field modeling in the Vesuvius and Campanian area. In: Zollo, A., et al. (Eds.), TomoVes Seismic Project: looking inside Mt.Vesuvius. Cuen, Napoli.

Capuano, P., Russo, G., Civetta, L., Orsi, G., D'Antonio, M., Moretti, R., 2013. The active portion of the Campi Flegrei calderastructure imaged by 3-D inversion of gravity data. Geochemistry, Geophysics, Geosystems 14 (10), 4681-4697.

Carmisciano, C., Grassi, M., Cocchi, L., Masetti, G., Filippone, M., Ricci, E., Pratellesi, M., Roberta Ivaldi, R., Iannaccone, G., Berrino, G., De Natale, G., Chiodini, G., Caliro, S., Dialti, L., Guideri, M., Muccini, F., Stefanelli, P., Orsi, G., Iafolla, V., Italiano, F., Buongiorno, F., Stramondo, S., Bignami, C., Polcari, M., Silvestri, M., 2013. RICAMAR2013: Rilievi per la caratterizzazione dell'ambiente marino nel Golfo di Pozzuoli. Rapporto sull'attività 13-31 maggio 2013. Rapporti Tecnici INGV n. 262, pp. $1-54$.

Cinque, A., Rolandi, G., Zamparelli, V., 1985. L'estensione dei depositi marini olocenici nei Campi Flegrei in relazione alla vulcano-tettonica. Bollettino della Società Geologica Italiana 327-348. 
Cole, J.W., Milner, D.M., Spinks, K.D., 2005. Calderas and caldera structures: a review. Earth-Science Review 69, 1-26.

D'Antonio, M., Civetta, L., Orsi, G., Pappalardo, L., Piochi, M., Carandente, A., de Vita, S., Di Vito, M.A., Isaia, R., 1999. The present state of the magmatic system of the Campi Flegrei caldera based on a reconstruction of its behavior in the past $12 \mathrm{ka}$. Journal of Volcanology and Geothermal Research 91, 247-268.

de Alteriis, G., Insinga, D.D., Morabito, S., Morra, V., Chiocci, F.L., Terrasi, F., Lubritto, C. Di, Benedetto, C., Pazzanese, M., 2010. Age of submarine debris avalanches and tephrostratigraphy offshore Ischia Island Tyrrhenian Sea, Italy. Marine Geology 278 (1-4), 1-18.

De Natale, G., Troise, C., Pingue, F., De Gori, P., Chiarabba, C., 2001. Structure and dynamics of the Somma Vesuvius volcanic complex. Mineralogy and Petrology 73, 5-22.

De Natale, G., Troise, C., Pingue, F., Mastrolorenzo, G., Pappalardo, L., Battaglia, M., Boschi, E., 2006. The Campi Flegrei Caldera: unrest mechanisms and hazards. In: Troise, C., De Natale, G., Kilburn, C.R.J. (Eds.), Mechanisms of Activity and Unrest at Large Calderas. Geological Society, London, Special Publications, 269, pp. 25-45.

De Pippo, T., Di Cara, A., Guida, M., Pescatore, T.S., Renda, P., 1984. Contributi allo studio del Golfo di Pozzuoli: lineamenti di geomorfologia. Memorie della Società Geologica Italiana 27, 151-159.

de Vita, S., Orsi, G., Civetta, L., Carandente, A., D'Antonio, M., Deino, A., di Cesare, T., Di Vito, M.A., Fisher, R.V., Isaia, R., Marotta, E., Necco, A., Ort, M., Pappalardo, L., Piochi, M., Southon, J., 1999. The Agnano-Monte Spina eruption (4100 years BP) in the restless Campi Flegrei caldera (Italy). Journal of Volcanology and Geothermal Research 91, 269-301.

De Vivo, B., Rolandi, G., Gans, P.B., Calvert, A., Bohrson, W.A., Spera, F.J., Belkin, H.E., 2001. New constraints on the pyroclastic eruptive history of the Campanian volcanic Plain (Italy). Mineralogy and Petrology 73, 47-65.

Deino, A.L., Orsi, G., de Vita, S., Piochi, M., 2004. The age of the Neapolitan Yellow Tuff caldera-forming eruption (Campi Flegrei caldera-Italy) assessed by $40 \mathrm{Ar} / 39 \mathrm{Ar}$ dating method. Journal of Volcanology and Geothermal Research 133, 157-170.

Dello Iacono, D., Zollo, A., Vassallo, M., Vanorio, T., Judenherc, S., 2009. Seismic images and rock properties of the very shallow structure of Campi Flegrei caldera (southern Italy). Bulletin of Volcanology 71, 275-284.

Di Girolamo, P., Ghiara, M.R., Lirer, L., Munno, R., Rolandi, G., Stanzione, D., 1984. Vulcanologia e petrologia dei Campi Flegrei. Bollettino della Società Geologica Italiana 103, 349-413.

Di Renzo, V., Arienzo, I., Civetta, L., D'Antonio, M., Tonarini, S., Di Vito, M.A., Orsi, G., 2011. The magmatic feeding system of the Campi Flegrei caldera: architecture and temporal evolution. Chemical Geology 281, 227-241.

Di Vito, M., Lirer, L., Mastrolorenzo, G., Rolandi, G., 1987. The Monte Nuovo eruption (Campi Flegrei, Italy). Bulletin of Volcanology 49, 608-615.

Di Vito, M.A., Isaia, R., Orsi, G., Southon, J., de Vita, S., D'Antonio, M., Pappalardo, L., Piochi, M., 1999. Volcanism and deformation in the past $12 \mathrm{ka}$ at the Campi Flegrei caldera (Italy). Journal of Volcanology and Geothermal Research 91, 221-246.

D'Oriano, C., Poggianti, E., Bertagnini, A., Cioni, R., Landi, P., Polacci, M., Rosi, M., 2005. Changes in eruptive style during the A.D. 1538 Monte Nuovo eruption (Phlegrean Fields, Italy): the role of syn-eruptive crystallization. Bulletin of Volcanology 67, 601-662.

Druitt, T.H., Sparks, R.S.J., 1984. On the formation of calderas during ignimbrite eruptions. Nature 310, 679-681.

Dvorak, J.J., Berrino, G., 1991. Recent ground movement and seismic activity in Campi Flegrei, southern Italy: episodic growth of a resurgent dome. Journal of Geophysical Research 96, 2309-2323.

Dvorak, J., Mastrolorenzo, G., 1991. The mechanisms of recent vertical crustal movements in Campi Flegrei caldera, southern Italy. Special Paper-Geological Society of America 263, 1-54.

Faccenna, C., Funiciello, F., Civetta, L., D’Antonio, M., Moroni, M., Piromallo, C., 2007. Slab disruption, mantle circulation, and the opening of the Tyrrhenian basins. In: Beccaluva, L., Bianchini, G., Wilson, M. (Eds.), Cenozoic Volcanism in the Mediterranean Area: Geological Society of America Special Paper, 418, pp. 153-169. http://dx.doi.org/10.1130/2007.2418(08).

Fedele, L., Insinga, D.D., Calvert, A.T., Morra, V., Perrotta, A., Scarpati, C., $2011 .{ }^{40} \mathrm{Ar} /{ }^{39} \mathrm{Ar}$ dating of tuff vents in the Campi Flegrei caldera (southern Italy): toward a new chronostratigraphic reconstruction of the Holocene volcanic activity. Bulletin of Volcanology 73, 1323-1336.

Ferranti, L., Oldow, J.S., Sacchi, M., 1996. Pre-Quaternary orogen-parallel extension in the Southern Apennine belt, Italy. Tectonophysics 260, 325-347.

Fevola, F., Fusi, N., Mirabile, L., 1993. Rilievi di sismica monocale ad alta risoluzione: aspetti dell'avoluzione geomorfologica del Golfo di Napoli. Annali dell Istituto Universitario Navale, Napoli 60, 61-71.

Florio, G., Fedi, M., Cella, F., Rapolla, A., 1999. The Campanian Plain and Phlegrean Fields: structural setting from potential field data. Journal of Volcanology and Geothermal Research 91, 361-379.

Folk, R.L., Ward, W.C., 1957. Brazos river bar: a study in the significance of grain-size parameters. Journal of Sedimentary Petrology 27, 3-26.

Fusi, N., Mirabile, L., Camerlenghi, A., Ranieri, G., 1991. Marine geophysical survey of the Gulf of Naples (Italy): relationships between submarine volcanic activity and sedimentation. Memorie della Società Geologica Italiana 47, 95-114.

Henry, C.H., Price, J.G., 1984. Variations in caldera development in the Tertiary volcanic field of Trans-Pecos Texas. Journal of Geophysical Research 89, 8765-8786.

Hoefs, J., 1987. Stable Isotope Geochemistry. Springer, Verlag pp. 170-175.

Insinga, D., Di Meglio, A., Molisso, F., Sacchi, M., 2002. Stratigrafia e caratteristiche fisiche dei depositi olocenici del porto di Miseno, Golfo di Pozzuoli (Tirreno centroorientale). Il Quaternario 15, 9-19.

Insinga, D., Calvert, A.T., Lanphere, M.A., Morra, V., Perrotta, A., Sacchi, M., Scarpati, C., Saburomaru, J., Fedele, L., 2006. The Late-Holocene evolution of the Miseno area (southwestern Campi Flegrei) as inferred by stratigraphy, petrochemistry and
${ }^{40} \mathrm{Ar} /{ }^{39} \mathrm{Ar}$ geochronology. In: De Vivo, B. (Ed.), Volcanism in the Campania Plain: Vesuvius, Campi Flegrei and Ignimbrites. Elsevier B. V, pp. 97-124.

Isaia, R., Marianelli, P., Sbrana, A., 2009. Caldera unrest prior to intense volcanism in Campi Flegrei (Italy) at 4.0 ka B.P.: implications for caldera dynamics and future eruptive scenarios. Geophysical Research Letters 36, L21303.

Judenherc, S., Zollo, A., 2004. The Bay of Naples (Southern Italy): constraints on the volcanic structures inferred from a dense seismic survey. Journal of Geophysical Research 109, B10312.

Kennedy, B., Stix, J., 2003. Stages in the temporal evolution of calderas. Geoscience Canada 30, 129-140.

Kennedy, B., Wilcock, J., Stix, J., 2012. Caldera resurgence during magma replenishment and rejuvenation at Valles and Lake City calderas. Bulletin of Volcanology 74 1833-1847.

Kokelaar, B.P., 1992. Ordovician marine volcanic and sedimentary record of rifting and volcanotectonism: Snowdon, Wales, U.K. Geological Society of America Bulletin $104,1433-1455$.

Komuro, H., 1987. Experiments on cauldron formation: a polygonal cauldron and ring fractures. Journal of Volcanology and Geothermal Research 31, 139-149.

Komuro, H., Fujita, Y., Kodama, K., 1984. Numerical and experimental models on the formation mechanism of collapse basins during the Green Tuff orogenesis of Japan. Bulletin of Volcanology 47, 649-666.

Lambeck, K., Antonioli, F. Anzidei, M., Ferranti, L., Leoni, G., Scicchitano, G., Silenzi, S. 2011. Sea level change along the Italian coast during the Holocene projections for the future. Quaternary International 232, 250-257.

Le Bas, M.J., Le Maitre, R.W., Streckeisen, A., Zanettin, B., 1986. A chemical classification of volcanic rocks based on the total alkali-silica diagram. Journal of Petrology 27. 745-750.

Lipman, P.W., 1984. The roots of ash flow calderas in Western North America: windows into the tops of granitic batholiths. Journal of Geophysical Research 89, 8801-8841.

Lipman, P.W., 1997. Subsidence of ash flow caldera: relation to caldera size and magma chamber geometry. Bulletin of Volcanology 59, 198-218.

Lipman, P.W., 2000. Calderas. In: Sigurdsson, H. (Ed.), Encyclopedia of Volcanoes. Academic Press, San Diego, pp. 643-662.

Lirer, L., Pescatore, T.S., Booth, B., Walker, G.P.L., 1973. Two Plinian pumice-fall deposits from Somma-Vesuvius, Italy. Geological Society of America Bulletin 84, 759-772.

Lirer, L., Luongo, G., Scandone, R., 1987. On the volcanological evolution of Campi Flegrei. EOS, Transactions of the American Geophysical Union 68, 226-234.

Loeblich, A.R., Tappan, H., 1988. Foraminiferal Genera and their Classification. Van Nostrand Reinhold, New York (970 pp.).

Malinverno, A., Ryan, W.B.F., 1986. Extension in the Tyrrhenian Sea and shortening in the Apennines as result of arc migration driven by sinking of the lithosphere. Tectonics 5 , 227-245.

Martí, J., Geyer, A., Folch, A., Gottsmann, J., 2008. A review on collapse calderas modeling. In: Gottsmann, J., Martí, J. (Eds.), Caldera Volcanism: Analysis, Modelling and Response. Developments in Volcanology, 10. Elsevier, pp. 233-283.

Martí, J., Geyer, A., Folch, A., 2009. Agenetic classification of collapse calderasbased on field studies, and analogue and theoretical modelling. In: Thordarson, T., Self, S., Larsen, G. Rowland, S.K., Höskuldsson, A. (Eds.), Studies in Volcanology: The Legacy of George Walker. Special Publications of IAVCEI. Geological Society, London., 2, pp. 249-266.

Melluso, L., Morra, V., Brotzu, P., Tommasini, S., Renna, M.R., Duncan, R.A., Franciosi, L. D'Amelio, F., 2005. Geochronology and petrogenesis of the Cretaceous Antampombato-Ambatovy complex and associated dyke swarm, Madagascar. Journal of Petrology 46, 1963-1996.

Melluso, L., de' Gennaro, R., Fedele, L., Franciosi, L., Morra, V., 2012. Evidence of crystallization in residual, $\mathrm{Cl}-\mathrm{F}-$ rich, agpaitic, trachyphonolitic magmas and primitive $\mathrm{Mg}$ rich basalt-trachyphonolite interaction in the lava domes of the Phlegrean Fields (Italy). Geological Magazine 149 (3), 532-550.

Milia, A., 1998. Stratigrafia, strutture deformative e considerazioni sull'origine delle unità deposizionali oloceniche del Golfo di Pozzuoli (Napoli). Bollettino Società Geologica Italiana 117, 777-787.

Milia, A., 1999. Aggrading and prograding infill of a peri-Tyrrhenian Basin (Naples Bay, Italy). Geo-Marine Letters 19, 237-244.

Milia, A., 2010. The stratigraphic signature of volcanism offshore Campi Flegrei (Naples Bay, Italy). In: Groppelli, G., Viereck-Goette, L. (Eds.), Stratigraphy and Geology of Volcanic Areas. Geological Society of America Special Paper, 464, pp. 155-170.

Milia, A., Giordano, F., 2002. Holocene stratigraphy and depositional architecture of eastern Pozzuoli Bay (eastern Tyrrhenian Sea margin, Italy): the influence of tectonics and wave-induced currents. Geo-Marine Letters 22 (1), 42-50.

Milia, A., Torrente, M.M., 2000. Fold uplift and syn-kinematic stratal architectures in a region of active transtensional tectonics and volcanism, Easter Tyrrhenian Sea. Geological Society of America Bulletin 112, 1531-1542.

Milia, A., Torrente, M.M., 2003. Late Quaternary volcanism and transtensional tectonics at the Campania continental margin Bay of Naples, Italy. Mineralogy and Petrology 79, 49-65.

Milia, A., Torrente, M.M., Zuppetta, A., 2003. Debris avalanches offshore of Somma-Vesuvius volcano, Italy: implications for volcanic hazard evaluation. Journal of the Geological Society, London 160, 309-317.

Milia, A., Molisso, F., Raspini, A., Sacchi, M., Torrente, M.M., 2008. Syneruptive features and sedimentary processes associated with pyroclastic currents entering the sea: the AD 79 eruption of Vesuvius, Bay of Naples, Italy. Journal of the Geological Society, London $165,839-848$.

Moore, I., Kokelaar, P., 1998. Tectonically controlled piecemeal caldera collapse: a case study of Glencoe volcano, Scotland. Geological Society of America Bulletin 110 1446-1466.

Morhange, C., Bourcier, M., Laborel, J., Giallanella, C., Goiran, J.P., Crimaco, L., Vecchi, L., 1999. New data on historical relative sea level movements in Pozzuoli, Phlaegrean Fields, southern Italy. Physics and Chemistry of the Earth, Part A 24 (4), 349-354. 
Newhall, C.G., Dzurisin, D., 1988. Historical Unrest at Large Calderas of the World: U.S Geological Survey Bulletin 1855 (1108 pp.).

Oldow, J.S., D'Argenio, B., Ferranti, L., Pappone, G., Marsella, E., Sacchi, M., 1993. Largescale longitudinal extension in the southern Apennines contractional belt, Italy. Geology $21,1123-1126$

Orsi, G., Gallo, G., Heiken, G., Wohletz, K., Yu, E., Bonani, G., 1992. A comprehensive study of the pumice formation and dispersal: the Cretaio Tephra of Ischia (Italy). Journal of Volcanology and Geothermal Research 53, 329-354.

Orsi, G., De Vita, S., Di Vito, M., 1996. The restless, resurgent Campi Flegrei nested caldera (Italy): constraints on its evolution and configuration. Journal of Volcanology and Geothermal Research 74, 179-214.

Orsi, G., Civetta, L., Del Gaudio, C., de Vita, S., Di Vito, M.A., Isaia, R., Petrazzuoli, S. Ricciardi, G., Ricco, C., 1999. Short-term ground deformations and seismicity in the nested Campi Flegrei Caldera (Italy): an example of active block resurgence in densely populated area. Journal of Volcanology and Geothermal Research 91, 415-451.

Pappalardo, L., Civetta, L., D'Antonio, M., Deino, A.L., Di Vito, M.A., Orsi, G., Caradente, A. De Vita, S., Isaia, R., Piochi, M., 1999. Chemical and Sr-isotopical evolution of the Phlegraean magmatic system before the Campanian Ignimbrite (37 ka) and the Neapolitan Yellow Tuff (12 ka) eruptions. Journal of Volcanology and Geothermal Research $91,141-166$

Parascandola, A., 1946. Il Monte Nuovo e il Lago Lucrino. Bollettino Società Naturalisti di Napoli 55, 151-312.

Passariello, I., Marzaioli, F., Lubritto, C., Rubino, M., D'Onofrio, A., De Cesare, N., Borriello, G. Casa, G., Palmieri, A., Rogalla, D., Sabbarese, C., Terrasi, F., 2007. Radiocarbon sample preparation at the Circe AMS laboratory in Caserta, Italy. Radiocarbon 49 (2), 225-232.

Passaro, S., Barra, M., Saggiomo, R., Di Giacomo, S., Leotta, A., Uhlen, H., Mazzola, S. 2012. Multi-resolution morpho-bathymetric survey results at the Pozzuoli-Baia underwater archaeological site (Naples, Italy). Journal of Archaeological Science 40 $1268-1278$

Pepe, F., Ferranti, L., Sacchi, M., Bertotti, G., Collura, A.M., Sulli, A., 2013. Pattern and rate of post-20 ka vertical tectonic motion around the Capo Vaticano Promontory (W Calabria, Italy) based on offshore geomorphological indicators. Quaternary International. http://dx.doi.org/10.1016/j.quaint.2013.11.012.

Pérès, J.M., Picard, J., 1964. Nouveau manual de Bionomie benthique de la Mer Méditerranée. Recueil des Travaux de la Station Marine d'Endoume 47 (31) 3-137.

Pescatore, T., Diplomatico, G., Senatore, M.R., Tramutoli, M., Mirabile, L., 1984. Contribut allo studio del Golfo di Pozzuoli: aspetti stratigrafici e strutturali. Memorie della Società Geologica Italiana 27, 133-149.

Piochi, M., Mastrolorenzo, G., Pappalardo, L., 2005. Magma ascent and eruptive processes from textural and compositional features of Monte Nuovo pyroclastic products, Campi Flegrei, Italy. Bulletin of Volcanology 67, 663-678.

Reimer, P.J., Bard, E., Bayliss, A., Beck, J.W., Blackwell, P.G., Bronk Ramsey, C., Buck, C.E. Cheng, H., Edwards, R.L., Friedrich, M., Grootes, P.M., Guilderson, T.P., Haflidason, H. Hajdas, I., Hatté, C., Heaton, T.J., Hoffmann, D.L., Hogg, A.G., Hughen, K.A., Kaiser, K.F., Kromer, B., Manning, S.W., Niu, M., Reimer, R.W., Richards, D.A., Scott, E.M., Southon, J.R., Staff, R.A., Turney, C.S.M., van der Plicht, J., 2013. IntCal13 and Marine13 radiocarbon age calibration curves $0-50,000$ years cal BP. Radiocarbon 55 (4), 1869-1887.

Roche, O., Druitt, T.H., Merle, O., 2000. Experimental study of caldera formation. Journal of Geophysical Research 105B, 395-416.

Rolandi, G., Bellucci, F., Heizler, M.T., Belkin, H.E., De Vivo, B., 2003. Tectonic controls on the genesis of ignimbrites from the Campanian Volcanic Zone, southern Italy. Mineral and Petrology 79, 3-31.

Rosi, M., Sbrana, A., 1987. The Phlegrean Fields. C.N.R. Quaderni de "La ricerca scientifica” (175 pp.).
Sacchi, M., Infuso, S., Marsella, E., 1994. Late Pliocene-Early Pleistocene compressional tectonics in offshore Campania (Eastern Tyrrenian sea). Bollettino di Geofisica Teorica ed Applicata 36 (141-144), 469-482.

Sacchi, M., Insinga, D., Milia, A., Molisso, F., Raspini, A., Torrente, M.M., Conforti, A., 2005. Stratigraphic signature of the Vesuvius 79 AD event off the Sarno prodelta system, Naples Bay. Marine Geology 222-223, 443-469.

Sacchi, M., Alessio, G., Aquino, I., Esposito, E., Molisso, F., Nappi, R., Porfido, S., Violante, C., 2009. Risultati preliminari della campagna oceanografica CAFE 07 - Leg 3 nei Golfi di Napoli e Pozzuoli, Mar Tirreno Orientale. Quaderni di Geofisica 64, 3-26.

Santacroce, R., Sulpizio, R., Zanchetta, G., Cioni, R., Marianelli, P., Sbrana, A., Donahue, D.J., Joron, J.L., 2008. Age and whole rocks-glass composition of proximal pyroclastics from the major explosive eruptions of Vesuvius: a review as a tool for distal tephrostratigraphy. Journal of Volcanology and Geothermal Research 177, 1-8.

Sartori, R., Torelli, L., Zitellini, N., Carrara, G., Magaldi, M., Mussoni, P., 2004. Crustal features along a W-E Tyrrhenian transect from Sardinia to Campania margins (Central Mediterranean). Tectonophysics 383, 171-192.

Saunders, S., 2001. The shallow plumbing system of Rabaul caldera: a partially intruded ring fault? Bulletin of Volcanology 63, 406-420.

Scandone, R., Bellucci, F., Lirer, L., Rolandi, G., 1991. The structure of the Campanian Plain and the activity of Neapolitan Volcanoes (Italy). Journal of Volcanology and Geothermal Research 48, 1-31.

Scarpati, C., Cole, P., Perrotta, A., 1993. The Neapolitan yellow Tuff - a large volume multiphase eruption from Campi Flegrei, Southern Italy. Bulletin of Volcanology 55, 343-356.

Scarpati, C., Perrotta, A., Lepore, S., Calvert, A., 2013. Eruptive history of Neapolitan volcanoes: constraints from ${ }^{40} \mathrm{Ar}-{ }^{39} \mathrm{Ar}$ dating. Geological Magazine 150, 412-425.

Sgarrella, F., Moncharmont Zei, M., 1993. Benthic foraminifera of the Gulf of Naples (Italy): systematics and autoecology. Bollettino della Società Paleontologica Italiana 32, 145-264.

Siani, G., Paterne, M., Arnold, M., Bard, E., Metivier, B., Tisnérat, N., Bassinot, F., 2000. Radiocarbon reservoir ages in the Mediterranean Sea and Black Sea. Radiocarbon 42 (2), 271-280.

Smith, R.L., Bailey, R.A., 1968. Resurgence cauldrons. Geological Society of America Memoirs 116, 613-662.

Smith, V.C., Isaia, R., Pearce, N.J.G., 2011. Tephrostratigraphy and glass compositions of post-15 kyr Campi Flegrei eruptions: implications for eruption history and chronostratigraphic markers. Quaternary Science Reviews 30, 3638-3660.

Terrasi, F., Rogalla, D., De Cesare, N., D'Onofrio, A., Lubritto, C., Marzaioli, F., Passariello, I., Rubino, M., Sabbarese, C., Casa, G., Palmieri, A., Gialanella, L. Imbriani, G., Roca, V. Romano, M., Sundquist, M., Loger, R., 2007. A new AMS facility in Caserta/Italy. Nuclear Instrument and Methods in Physics Research, Section B 259, 14-17.

Troise, C., De Natale, G., Pingue, F., Obrizzo, F., De Martino, P., Tammaro, U., Boschi, E., 2007. Renewed ground uplift at Campi Flegrei caldera (Italy): new insight on magmatic processes and forecast. Geophysical Research Letters 34, L03301.

Ukawa, M., Fujita, E., Ueda, H., Kumagai, T., Nakajima, H., Morita, H., 2006. Long-term geodetic measurements of large scale deformation at Iwo-jima caldera, Japan. Journal of Volcanology and Geothermal Research 150, 98-118.

Vogel, J.S., Southon, J.R., Nelson, D.E., Brown, T.A., 1984. Performance of catalytically condensed carbon for use in accelerator mass spectrometry: Nuclear Instruments and Methods 223 B5, 289-293.

Walker, G.P.L., 1984. Downsag calderas, ring faults, caldera sizes, and incremental caldera growth. Journal of Geophysical Research 89B, 8407-8416.

Wohletz, K., Orsi, G., De Vita, S., 1995. Eruptive mechanism of the Neapolitan Yellow Tuff interpreted from stratigraphic, chemical and granulometric data. Journal of Volcanology and Geothermal Research 67, 263-290. 